\title{
LATE GLACIAL AND HOLOCENE PALEOGEOGRAPHICAL AND PALEOECOLOGICAL EVOLUTION OF THE SENO SKYRING AND OTWAY FJORD SYSTEMS IN THE MAGELLAN REGION
}

\author{
EVOLUCIÓN PALEOGEOGRÁFICA Y PALEOECOLÓGICA DEL SISTEMA DE FIORDOS \\ DEL SENO SKYRING Y SENO OTWAY EN LA REGIÓN DE MAGALLANES DURANTE EL \\ TARDIGLACIAL Y HOLOCENO
}

\author{
Kilian, R. ${ }^{1}$, Baeza, O. ${ }^{1}$, Breuer, S., Ríos, F. ${ }^{1}$, Arz, H. ${ }^{2}$, Lamy, F. ${ }^{3}$, Wirtz, J. ${ }^{1}$, Baque, D. ${ }^{1}$, Korf, P. ${ }^{1}$, \\ Kremer, K. ${ }^{1}$, Ríos, C. ${ }^{4}$, Mutschke, E. ${ }^{5}$, Simon, M. ${ }^{1}$, De Pol-Holz, R. ${ }^{6}$, Arevalo, M. ${ }^{7}$, Wörner, G. ${ }^{8}$, \\ Schneider, C. ${ }^{9}$ \& Casassa, G. ${ }^{10}$
}

\section{RESUMEN}

Los sistemas de terrazas evidencian que el Seno Otway y Skyring y el fiordo de Última Esperanza, formaron el mayor sistema lacustre proglacial interconectado de la Patagonia Austral $\left(5.700 \mathrm{~km}^{2}\right)$ durante la deglaciación temprana (< 18 a $\left.14 \mathrm{ka} \mathrm{BP}\right)$. Este sistema drenaba por el este del Seno Otway hacia el Atlántico. El retroceso de los glaciares desde el Canal Jerónimo alrededor de 14,0 cal kyr causó un mega evento de desagüe $\left(320 \mathrm{~km}^{3}\right)$, que bajó 95 metros el nivel lacustre en el Seno Otway e inició una transgresión marina, así como una intensa erosión a largo plazo de las líneas de costa que quedaron expuestas alrededor del Seno Otway. Entre 11 a $10 \mathrm{ka}$ BP se produjo una transgresión marina más limitada en el sector oriental del Seno Skyring, probablemente a través del Canal Gajardo. Esto fue causado por el retroceso de los glaciares alrededor del Gran Campo Nevado (GCN) durante el Máximo Termal del Holoceno Temprano en el Hemisferio Sur (después de 12 ka BP). Las salinidades del Seno Otway (28-30 psu) y Seno Skyring (17-21 psu) se mantuvieron bajas durante todo el Holoceno. Sin embargo, ocurrieron acotadas variaciones de salinidad debido a nuevos cambios isostáticos en la entrada de agua marina, así también por cambios en la interrelación entre precipitación / evaporación. Estos afectaron la floculación de los minerales de arcilla, el transporte de sedimentos y también a los ecosistemas acuáticos. En particular, el avance de los hielos neoglaciales modificaron el grado de la transgresión marina en este sector andino debido al cierre de los fiordos y a efectos isostáticos. Los glaciares cerraron el Canal Gajardo y la salida de Lago Muñoz Gamero al menos varias veces en los períodos de 3,0-2,2 y 1,0-0,1 ka BP, dejando algunas huellas características de

\footnotetext{
${ }^{1}$ Geologie, FBVI, Universität Trier, Behringstr. 16, 54826 Trier, Germany.

2 Leibniz Institute for Baltic Sea Research Warnemünde, Seestr. 15, 18119 Rostock-Warnemünde, Germany.

${ }^{3}$ Alfred Wegener Institut für Polar- und Meeresforschung, Am Alten Hafen 26, 27568 Bremerhaven, Germany.

${ }^{4}$ Instituto de la Patagonia, Universidad de Magallanes, Av. Bulnes 01855, Punta Arenas, Chile.

${ }^{5}$ Instituto de la Patagonia, Laboratorio de Hidrobiología, Universidad de Magallanes, Av. Bulnes 01855, Punta Arenas, Chile.

${ }^{6}$ Departamento de Oceanografía, Universidad de Concepción, Casilla 160-C, 4070386 Concepción, Chile.

7 Geoestudios Ltda. Santiago, Chile.

${ }^{8}$ Geowissenschaftliches Zentrum Göttingen, Geochemie, Universität Göttingen, Goldschmidtstr. 1, D-37077 Göttingen, Germany.

${ }^{9}$ Department of Geography, RWTH Aachen University, D-52056 Aachen, Germany.

${ }^{10}$ Geoestudios Ltda. Santiago, Chile; Universidad de Magallanes, Punta Arenas, Chile.
} 
arcilla glacial en los sedimentos de los Senos Otway y Skyring. Las regiones de fiordos con pendientes más pronunciadas al oeste de los Senos Skyring y Otway también se vieron afectados por los eventos de flujo de masa regulares, en parte provocados por terremotos y eventos de precipitaciones extremas.

Palabras clave: Sistema lacustre proglacial, Canal Jerónimo, transgresión, Canal Gajardo, Holoceno.

\section{ABSTRACT}

Terrace systems indicate that the Seno Otway and Skyring, and the Última Esperanza fjord formed the largest interconnected proglacial lake system of southern Patagonia $\left(5700 \mathrm{~km}^{2}\right)$ during the early deglaciation ( $<18$ to $14 \mathrm{kyr} \mathrm{BP}$ ). It drained through the eastern Seno Otway towards the Atlantic. The retreat of glaciers from the Jerónimo Channel at around 14.0 cal kyr caused a mega outflow event (320 $\mathrm{km}^{3}$ ) which lowered the Seno Otway lake level by $95 \mathrm{~m}$ and initiated a marine transgression as well as an intensive long term erosion of newly exposed shore lines around the Seno Otway. Between 11 to $10 \mathrm{kyr}$ BP a more limited marine transgression occurred to the eastern sector of Seno Skyring, probably through the Gajardo Channel. This was caused by a further glacier retreat around the Gran Campo Nevado Ice Cap (GCN) during the early Holocene southern hemisphere thermal maximum (after $12 \mathrm{kyr} \mathrm{BP}$ ). The salinities of the Seno Otway (28-30 psu) and Seno Skyring (17-21 psu) remained low throughout the Holocene. However, restricted salinity variations occurred due to further isostatic changes affecting the marine water inflow across sills as well as the interplay of precipitation/evaporation. The salinity changes affected clay mineral flocculation and sediment transport as well as aquatic ecosystems. In particular, Neoglacial glacier advances modified the degree of the marine transgression in this Andean sector due to closure of fjords and isostatic effects. Glaciers closed the Gajardo Channel and the outflow of Lago Muñoz Gamero at least several times in the periods from 3.0 to 2.2 and from 1.0 to $0.1 \mathrm{kyr} B P$, and left some glacial clay fingerprints in Seno Otway and Skyring sediments. Aquatic environment in fjord regions with stepper slopes in the western Seno Skyring and Otway area were also affected by regular mass flow events, partly triggered by earthquakes and events of extreme precipitation. Holocene tephra depositon caused additional impacts.

Key words: Proglacial lacustrine system, Jerónimo Channel, Transgression, Gajardo Channel, Holocene.

\section{INTRODUCTION}

The most extended glacier advances in the Magellan region occurred previously to the Late Glacial Maximum (LGM) at around 25 to $>30 \mathrm{kyr}$ BP (Caniupán et al. 2011; Kaplan et al. 2008; Sugden et al. 2005, 2009). At that time the Seno Skyring glacier may have reached until Laguna Blanca and the Seno Otway glaciers joined the glacier of the Strait of Magellan near to Segunda Angostura as drumlin directions indicate (Glacier limit A in Fig. 1, Lovell et al. 2011). The Late Glacial glacier retreat from the present day western shores of Seno Otway and Skyring occurred soon after 19 ka BP (Retreat stages B and C; Clapperton et al. 1995; Kilian et al. 2007a; McCulloch et al. 2005). Late Glacial to early Holocene glacier retreat phases (stages $\mathrm{D}, \mathrm{E}$ ) have been previously suggest for the Seno Skyring based on subaquatic moraine systems and sediment records which have been correlated to advances in the Strait of Magellan (Fig. 1; Kilian et al. 2007a). During the ice retreat from 19 to $14 \mathrm{kyr}$ BP several proglacial lakes were formed on the eastside of the icedivide of the Patagonian Ice Field, in particular along the large ice streams which partly followed graben systems running perpendicular to the Andean mountain chain (Diraison et al. 1997). Terrace systems indicate that the Última Esperanza, Seno Otway and Seno Skyring formed the largest interconnected proglacial lake system of Patagonia (5700 km²; Fig. 1; Stern et al. 2011), nearly four times the size of the Lago Argentina $\left(1490 \mathrm{~km}^{2}\right)$. This lake system was draining towards the Atlantic. However, some of the large ice streams have eroded deep subglacial valleys along several transform fault systems which partly run across the higher elevated Andes (Breuer et al. 2013). 
Thus the proglacial lakes became episodically and/ or continuously connected with the fjord systems of the Pacific Coast of southernmost Chile during the further ice retreat. This multiphase marine transgression across the Andes was controlled by the interplay between glacier retreat as well as the global sea level rise and the degree of isostasy (Boyd et al. 2008; Kilian et al. 2007a; Stern et al. 2011). Consequently, changes in salinity and fjord currents strongly modified the aquatic ecosystems and associated terrestrial flora (more sea spray) and fauna (e.g. birds with aquatic food sources). The key-locations where the Seno Skyring, Seno Otway and Última Esperanza fjord could have been interconnected and where possible outflows as well as marine transgressions could have been appeared are illustrated in Figs. 1 to 3.

Due to the restricted pathways towards the more open western fjord system, semihaline (brackish) aquatic systems evolved with salinity

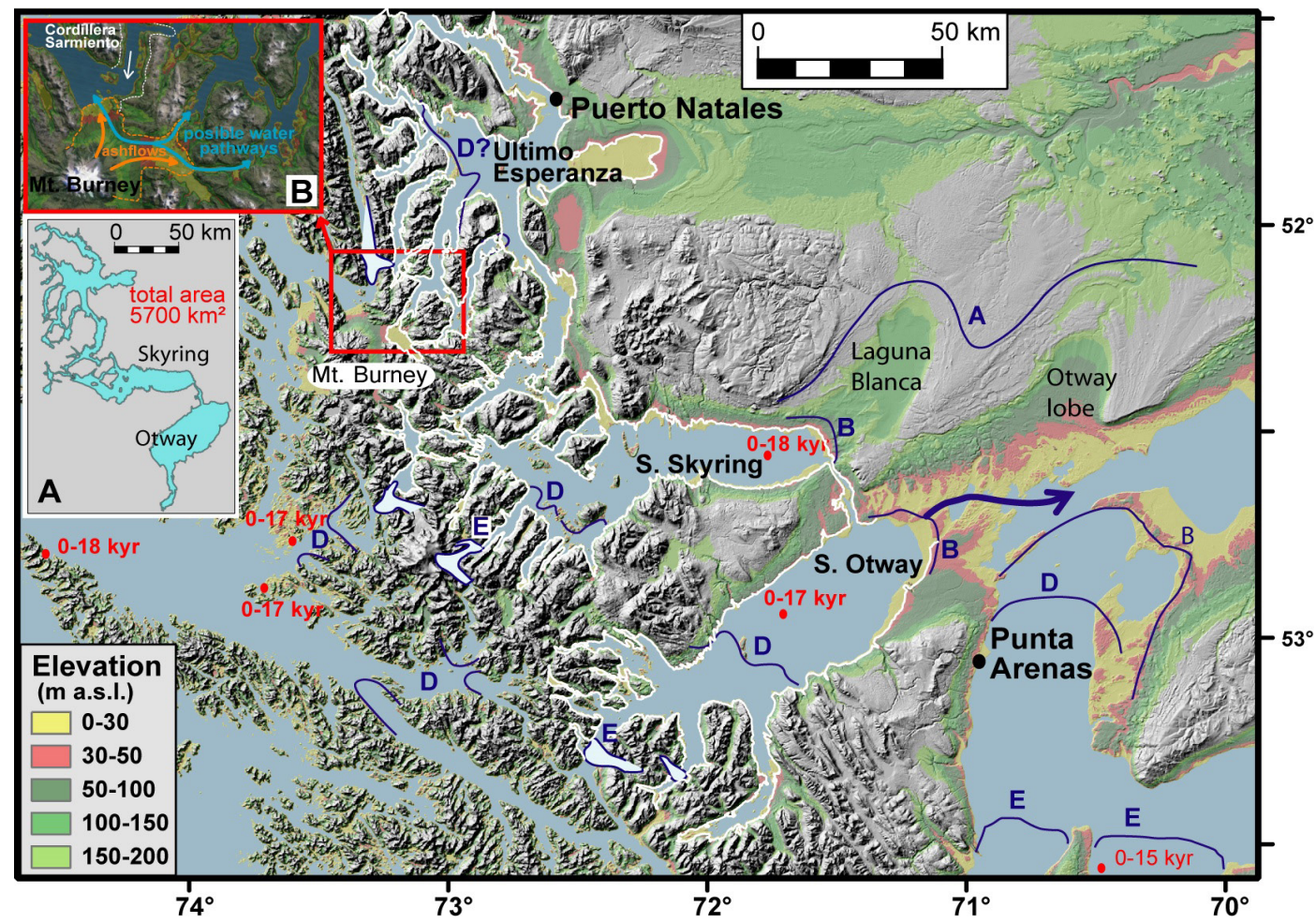

Fig. 1. The southernmost Andes with the distribution of the proglacial Late Glacial Magellan Lake system (white coast-line and inset map A, left). Approximate glacier positions at around 16 kyr BP (Stage D; Clapperton et al. 1995, Kilian et al. 2007, McCulloch et al. 2005) and after 14 kyr BP (Stage E) are indicated. Red dots with ages in kyr indicate ice-free conditions at these sediment core sites. The inset map (B, upper left) shows possible water path ways around the Mt. Burney previously to the deposition of ash-flows by the Mt. Burney eruption at around 9.05 kyr BP within previous fjord channels.

threshold levels (<30 psu) for different species (e.g. Horton \& Murray, 2007). The Última Esperanza fjord, the Seno Otway (salinities of 26-30 psu) and Seno Skyring (salinities of 17-19 psu) represent such newly formed fjord systems which experienced significant salinity changes during the Late Glacial and Holocene. Based on sediment core proxies this study intends to reconstruct the timing and degree of the marine transgression which changes in the sediment transport (e.g. clay flocculation; McCool \& Parson, 2004; Portela et al. 2013). Besides the marine transgression these sediment cores indicate several events (tephra deposition, mass flows, and precipitation events) which had further implication for the aquatic ecosystems. Furthermore, the present day thermohaline structures of the water 


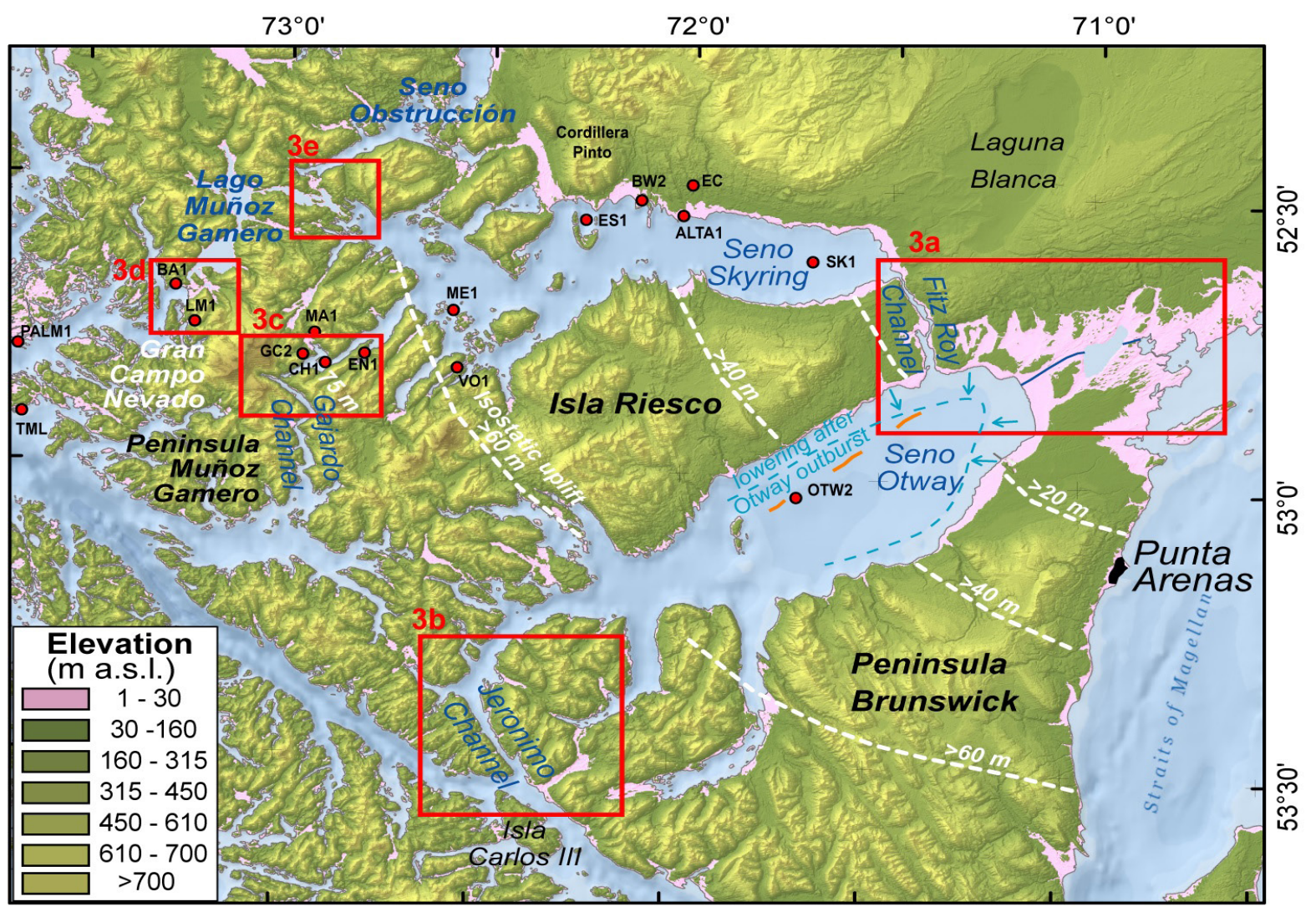

Fig. 2. Topographic map of Seno Skyring and Seno Otway area with locations of considered sediment records from fjord and lakes. Present day coast levels lower than $30 \mathrm{~m}$ are marked in pink since they represent possible past water pathways and include the T2 terrace system. Red squares represent key areas for possible past water pathways and marine transgressions which are illustrated in Fig 3. White stippled lines indicate the approximate isostatic uplift since the LGM and T1 terrace system. Orange lines in the Seno Otway mark the tracks of echosounding profile shown in Fig. 8.

columns have been investigated and considered in the context of present day and possible past in- and out-flow water pathways.

\section{METHODOLOGY}

Bathymetry, sediment echo sounding and coring

The fjord bathymetry and sediment structures of the Seno Otway and Skyring region were systematically investigated with the Parametric Echo Sounder System SES96 from INNOMAR and with a multi-beam echo sounder (ELAC Seabeam 1180 provided by GEOMAR, Kiel) operated on board of RV Gran Campo II between 2002 and 2012. Special attention was given to basin structures, subaquatic terraces and moraine structures (Breuer et al. 2013; Kilian et al. 2007b) and the echograms have been used to define coring sites.

Sediment cores were retrieved from board of Gran Campo II with a $5 \mathrm{~m}$ long UTWIC piston corer which enables up to $14 \mathrm{~m}$ deep drilling into the sediment. Discontinuous drilling was performed with $1 \mathrm{~m}$ overlapping of individual sections. 0.5 to $1 \mathrm{~m}$ long gravity cores were taken to obtain an undisturbed sediment surface. The overlapping between single core segments was controlled by high resolution core scanning with in-situ XRF and magnetic susceptibility sensors.

The locations of previously analysed and four new sediment cores from the Seno Otway and Seno Skyring area are shown in Fig. 2. The $4.82 \mathrm{~m}$ long sediment core OTW2 was retrieved in the middle sector of Seno Otway (52 $57.976^{\circ}$ S, 


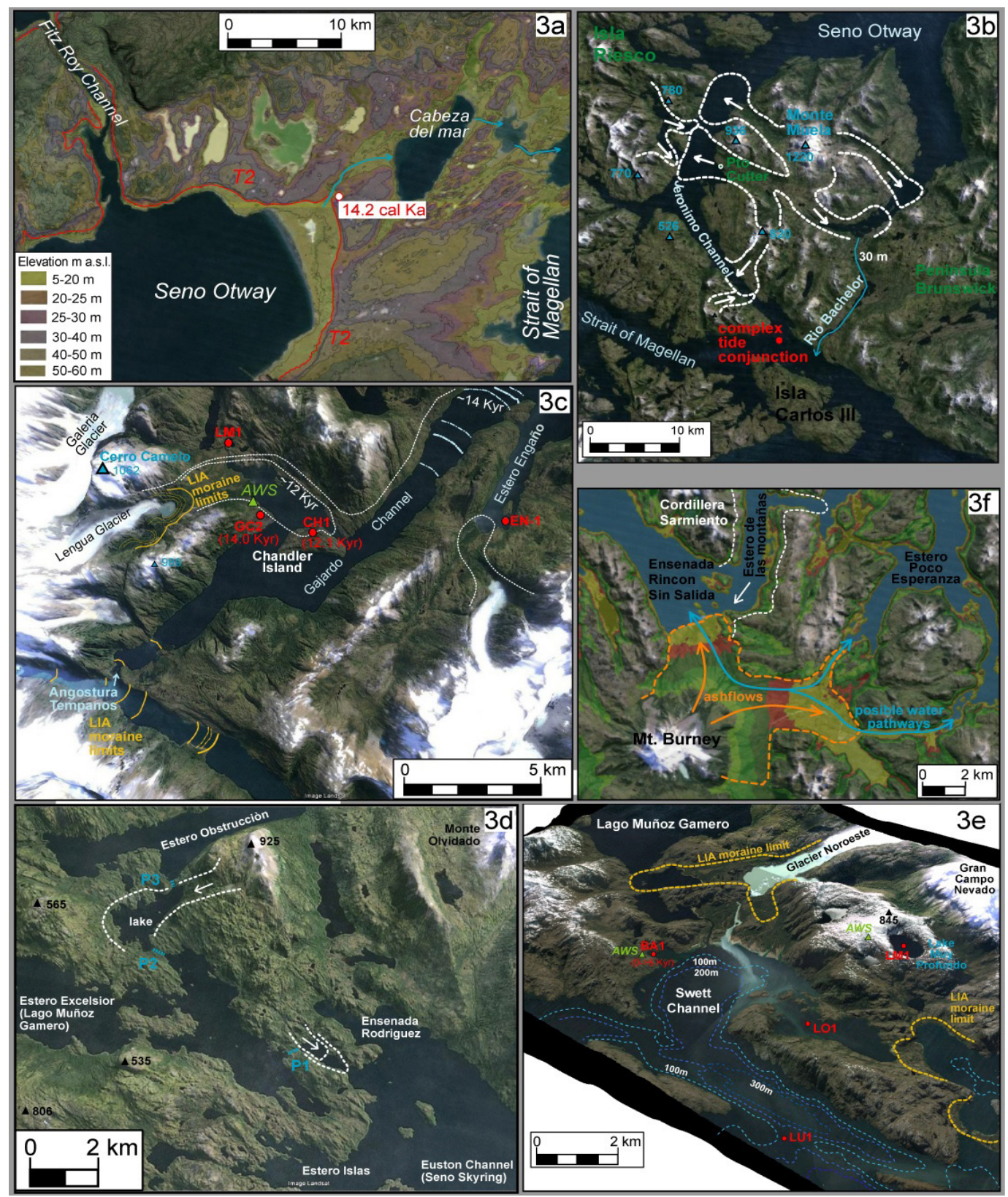

Fig. 3. Key areas for present day and past water pathways (indicated in Fig. 2) and marine transgression of the Magellan proglacial lake system with sediment site locations (in red): a) topography of the paleo-outflow region at the eastern shores of Seno Otway with the T2 terraces indicated by a redline. Blue arrows marks the spillway; b) Jerónimo Channel with probable Late Glacial glaciers previous to 14 kyr BP (dashed white lines); c) Gajardo Channel with moraine limits of Late Glacial (white lines) and Little Ice Age (yellow line, after Kilian et al. 2007a), Paso de Indios connections between Skyring, Lago Muñoz Gamero and Seno Obstrucción (with the paleochannels P1 to P3and potential glaciers limits during the Late Glacial) and f) western outflow region of the Última Esperanza Fjord around the Canal de las Montañas and the Mt. Burney volcano. Glaciers of the Canal de las Montañas could have been close the Rincón Sin Salida until around 12 kyr BP (Stern et al. 2011). Yellow arrows indicate ashflows from the 4.15 and 9.05 kyr BP eruptions which could have closed previous water pathways marked with a blue arrow. 
$72^{\circ} 01.288^{\prime} \mathrm{W}$ ) at $74.5 \mathrm{~m}$ water depth. The 8.86 $\mathrm{m}$ long sediment core ALTA1 was sampled in the Altamirano bay at the northern Skyring shores (52 $\left.33.351^{\prime} \mathrm{S} ; 2^{\circ} 01.288^{\prime} \mathrm{W}\right)$ at a water depth of $35 \mathrm{~m}$. The $8.20 \mathrm{~m}$ long core BW2 was retrieved at $38 \mathrm{~m}$ water depth in the Bahía Williams, located $7 \mathrm{~km}$ westward of Bahía Altamirano. The 11.75 $\mathrm{cm}$ long sediment core EN1 was retrieved at 37 $\mathrm{m}$ water depth from the Enga fjord $\left(52^{\circ} 49.454\right.$ 'S $72^{\circ} 48.201^{\prime} \mathrm{W}$ ) which is a $5 \mathrm{~km}$ long fjord branch associated to the north-north-eastern Gajardo Channel. The former sediment cores were investigated in the context of the diploma thesis of Korf $\left(2010^{1}\right)$ and Baque $\left(2010^{2}\right)$ as well as the master thesis of Kremer $\left(2009^{3}\right)$.

\section{Sediment core analytics}

Stratigraphy

${ }^{14} \mathrm{C}$-AMS ages have been determined at the NOSAMS (Woods Hole Oceanographic Institution) and the Leibniz AMS ${ }^{14} \mathrm{C}$ laboratories on shell and plant remnants. The radio-carbon ages have been calibrated using Calib7.0 and the SHCal13 Southern Hemisphere calibration dataset (Hogg et al. 2013). Reservoir ages are calculated from age/ depth relationships of well-dated tephra layers in the cores. They are typically in the range of 300 to 400 years. The ages of tephra layers are based on radiocarbon dates in terrestrial environments (lakes and peat bogs) and are thus independent of marine reservoir age assumptions (Kilian et al. 2003; 2007a; Stern, 2008). The stratigraphy of the new sediment cores ALTA1, EN1, OTW2 and BW2 is shown in Fig. 4.

\section{Sedimentological proxies}

TC, TN and TOC were measured on a Vario EL III CHNOS Elemental Analyzer at the

1 Korf, P. 2010. Der Ursprung von Biogenen Komponenten und Subaquatischen Gasaustritten (Pockmarks) in Fjordsedimenten Der Patagonischen Südanden. Diplomarbeit zur Erlangung des akademischen Grades Diplom-Geograph, Universität Trier. 2 Baque, D. 2010. Paläoklimatische Untersuchungen an holozänen Fjordsedimenten der Südanden. Diplomarbeit zur Erlangung des akademischen Grades Diplom-Geograph, Universität Trier.

3 Kremer, K. 2009. Patagonian Fjord Sediment Core as Holocene Climate Archive. Thesis to obtain the academic degree of Master in Geoscience, Georg-August-Universität Göttingen.
Alfred Wegener Institute (AWI-Bremerhaven) and a CarloErba Elementar Analysator NC2500 at the GeoForschungsZentrum Potsdam (GFZ). Previous to the analysis, all samples were freeze-dried and homogenized using an agate mortar and pestle. Calcium carbonate was calculated according to theformula $\mathrm{CaCO}_{3}=(\mathrm{TC}-\mathrm{TOC}) * 8.333$, where TC is the total carbon content on untreated samples and TOC is the total organic carbon content on $\mathrm{HCl}$-treated samples.

The chemical composition (major elements) of the sediment cores EN1, OTW2, BW2 and ALTA1 was measured in situ with an Avaatech ${ }^{\mathrm{TM}}$ X-Ray Flourescence (XRF) Core Scanner at the AWI-Bremerhaven. This non-destructive measuring technique allows semi-quantitative geochemical analysis of split sediment cores with a resolution of $<1 \mathrm{~cm}$ (Richter et al. 2006). Measurements were carried out with a rhodium anode and a voltage of $10 \mathrm{kV}$ and current range at $0.3 \mathrm{~mA}$. No filter was used.

The chemical composition of the major elements ( $\mathrm{Si}, \mathrm{Ti}, \mathrm{Al}, \mathrm{Mn}, \mathrm{Fe}, \mathrm{Mg}, \mathrm{Ca}, \mathrm{Na}, \mathrm{K}$ ) in representative and dried sediment samples have been analyzed also by atom absorption spectrometry at University of Trier. Considering the loss of ignition, the total sums of the oxides were in-between 99 and 101 wt.\%.

In order to determine grain sizes and clay mineral composition selected sediment samples were first shaken in a solution of hydrogen peroxide $(10 \%)$ to disaggregate and remove the organic matter. Coarse fraction with grain sizes $>63 \mu \mathrm{m}$ was separated by wet sieving. For division of silt $(2-63 \mu \mathrm{m}$ grain size) and clay $(<2 \mu \mathrm{m}$ grain size $)$ fractions the method of Atterberg was used. All fractions were weighted after drying for calculating the grain-size distribution.

Morphology and distribution terrace and present day and past water pathways

Terrace altitudes were measured by differential GPS at 20 profiles perpendicular to the coast lines (Fig. 7) and related to associated terrace systems along the Northern and Eastern shores of Seno Skyring, the Fitz Roy Channel and the eastern Sector of Seno Otway. The regional distribution of the identified terraces was mapped 


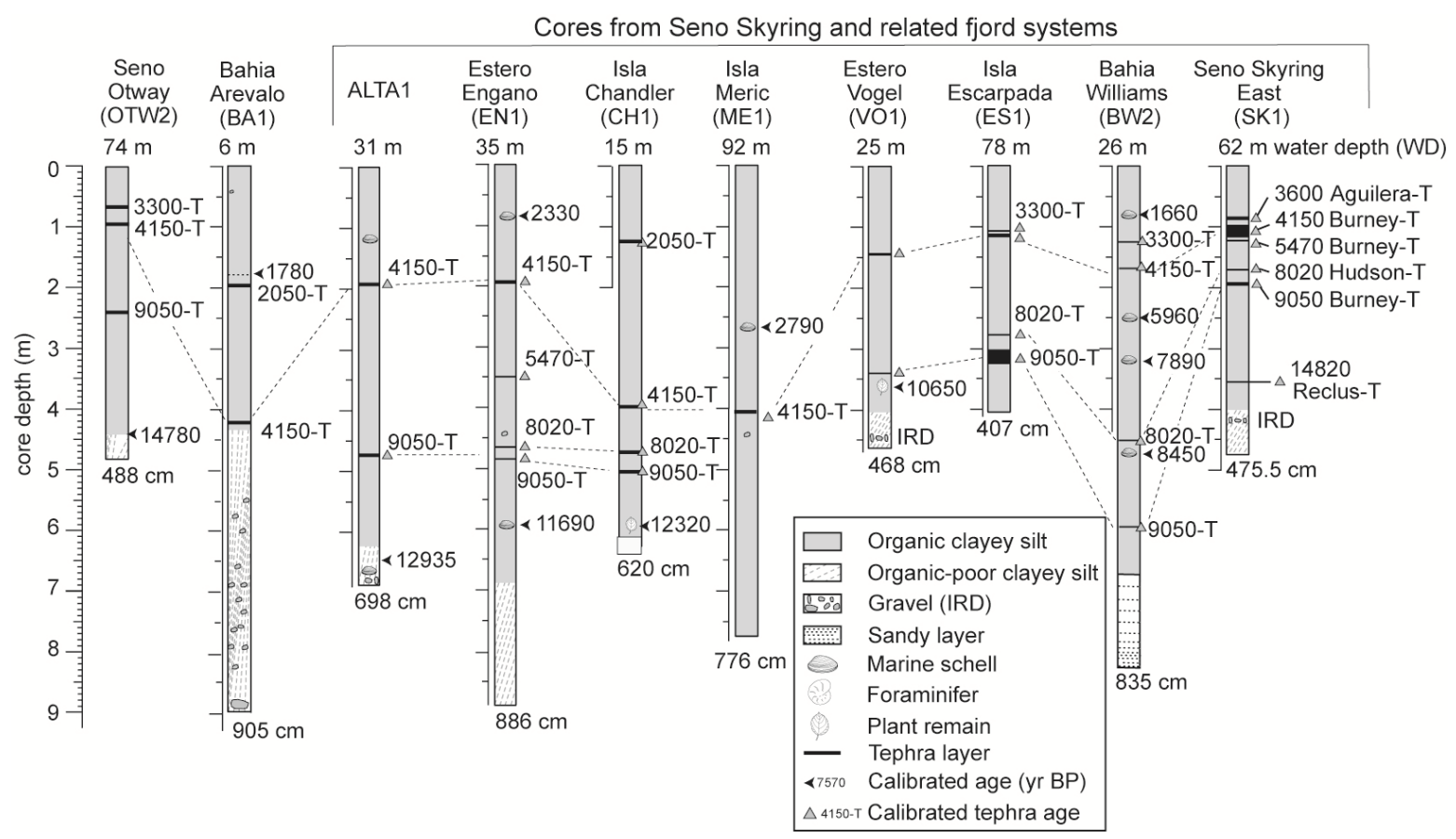

Fig. 4. Sediment cores with core depths of lithologies, ${ }^{14} \mathrm{C}$ ages and determined tephra layer (marked with -T after Kilian et al. 2003 and Stern 2008; see text) and tephrochronology of considered fjord and lake sediment records including sites (see Fig. 2). The cores include from left to right sites from: Seno Otway (OTW2), Bahia Arevalo (BA1), Bahia Altamirano (ALTA1), Estero Engaño (EN1), Isla Chandler (CH1), Isla Meric (ME1), Estero Vogel (VO1), Isla Escarpada (ES1), Bahia Williams (BW2) and Seno Skyring (SK1).

in the field and by remote sensing analyses of the Radar Shuttle Topography Mission in 2000.

The morphological and sedimentological characteristics of present day and past water pathways have been investigated in the field and by remote sensing data. Present day water depths along such passages have been investigated by echo sounder system SES2000 of Innomar.

Hydrology, weather station and thermohaline conditions

Water pressure sensors was measured near to Angostura Témpanos in Bahía Bahamondes (Sauter et al. 2009) and at the outflow of the proglacial lake of the Glacier Noroeste of the GCN (Fig. 3e) for estimates on water levels and its relationship to tides and precipitation (using Aquitronic CTD logger systems). Hydrological stations have been installed in the Swett area and near Angostura Témpanos and Fitz Roy Channel
(Fig. 3; Marangunic et al. 1992).

Automatic weather stations (AWS) were installed since 1999 along a fjord transect across the Andes between latitudes of $52^{\circ}$ and $53^{\circ} \mathrm{S}$ (Schneider et al. 2003, 2007). This network includes five Campbell Automatic Weather Stations: one AWS is working since 13 years at Estancia Skyring near the Río Pérez (Fig. 2). Two AWS are operating at the Bahía Bahamondes and on a ridge at $450 \mathrm{~m}$ altitude on the Northeast side of the GCN (Fig. 3c) and two stations are measuring at the Swett Channel area to the West of the GCN (Fig. 3 e).

Along the investigated fjord system regular CTD measurements have been performed with a CTD/STD sensor system (model SD204) from SAIV A/S environmental sensors \& systems and with an Aquitronic Multilogger systems (Kilian et al. 2007b) 


\section{RESULTS}

New sediment cores

Stratigraphy

The stratigraphy is based on tephra layers and ${ }^{14} \mathrm{C}$ ages from macro remnants of plants and shell fragments. The age frame of newly investigated and previously investigated sediment cores from the Seno Otway and Skyring area is illustrated in Fig. 4. The oldest tephra of Reclus volcano has been dated to around of the $15.0 \mathrm{kyr}$ BP (Kilian et al. 2003; McCulloch et al. 2005; Stern, 2008) and was only detected in the Sk1 sediment core. For the older Holocene eruption of the Mt. Burney a large range of possible ages 8.6 to 9.6 have been proposed (Kilian et al. 2007a,b, 2003; Stern, 2008). Based on ${ }^{14} \mathrm{C}$ ages of our sediment cores we propose an age of 9.05 kyr BP. This tephra was detected in most of the sediment cores. However, the thickness of this layer increases strongly towards the northern shore of Seno Skyring where it reaches 10 to $15 \mathrm{~cm}$. The 8.1 kyr old tephra layer of Hudson volcano (Stern, 2008) was also preserved in several cores as a 1 to $4 \mathrm{~mm}$ thick layer. The tephra of the 4.15 kyr BP eruption of the Mt. Burney (Kilian et al. 2003; Stern, 2008) was detected in all sediment cores. The highest tephra thick ness of $>10 \mathrm{~cm}$ was found in the LMP1, BA1 and MA1 and CH1 cores near to the GCN which indicates a southsoutheast distribution of the tephra plume. The 2.05 kyr BP eruption of the Mt. Burney (Kilian et al. 2006; Schimpf et al. 2011) was detected in the MA1 stalagmite record, the LMP1 and BA1 and $\mathrm{CH} 1$ core as $1-3 \mathrm{~mm}$ thick layer.

\section{XRF data}

Along core chemical variations of the OTW2 core from Seno Otway cover the last 16 kyr BP (Fig. 5). The chlorine content reflects mainly variations in the salinity and amount of pore water. It can be questioned how far the pore water represents an open system. However, the chlorine content correlates with the $\mathrm{Al} / \mathrm{Si}, \mathrm{Mn} / \mathrm{Fe}$ and $\mathrm{K} / \mathrm{Ti}$ ratios, which indicates changes in the mineralogical composition during the sedimentation which can indicate salinity changes during sedimentation. On the basis of the chlorine content, changes in the original salinity of the lake/fjord system can be determined, as also discussed by Kilian et al. (2013).

In the OTW2 core a significant increase in chlorine content occurred after around 14.0 kyr BP and this could indicate a first marine transgression. This change is associated with a pronounced increase in $\mathrm{K} / \mathrm{Ti}, \mathrm{Al} / \mathrm{Si}$ and $\mathrm{Mn} /$ Fe ratios indicating more clayey sediment and a change in sediment sources. In particular high $\mathrm{K} /$ $\mathrm{Si}$ ratios indicate more Illit-rich sediments which are typical for the Patagonian Batholith located $50 \mathrm{~km}$ further to the west. The amount of these glacial clay-bearing sediments is very high until $11 \mathrm{kyr}$ BP. From 11.0 to 7.0 kyr BP the above described chemical proxies for Andean-derived longdistance sediment transport decrease. Regarding the Holocene on a millennium-scale phases with higher chlorine content were accompanied by less allochtonous sediment probably due to salinity dependent controlled clay-flocculation (McCool \& Parson 2004; Portelo et al. 2013).

Chemical variations of the EN1, BW2, ALTA1 and SK1 sediment cores are summarised in Fig. 6. A significant increase in accumulation rates of biogenic carbonate started in the SK1 core at around $10.5 \mathrm{kyr} \mathrm{BP}$ soon after the Andean glacial clay signature (high $\mathrm{K} / \mathrm{Si}$ and $\mathrm{Al} / \mathrm{Si}$ ratios) has been decreased significantly from 11.5 to 10.5 kyr BP (Fig. 6a,b,c). The ALTA1, BW2 and EN1 sediment cores show a first significant increase in chlorine content between 10.5 and 9.5 kyr BP. This was also accompanied by a decrease in the chemical signature of Andean clay (lower $\mathrm{Al} / \mathrm{Si}$, $\mathrm{K} / \mathrm{Si}$ ratios). In the ALTA1 core the $\mathrm{Mn} / \mathrm{Fe}$ ratios reach low values after $8 \mathrm{kyr} \mathrm{BP}$ which remain low until present similar to that of the OTW2 core (Fig. $5 d)$.

The ALTA1 and BW2 cores show higher $\mathrm{K} / \mathrm{Si}$ and $\mathrm{Al} / \mathrm{Si}$ ratios together with higher chlorine content during two Holocene periods from 3.5 to 2.5 and from 1.0 to $0.1 \mathrm{kyr}$ BP. In particular the BW2 core is characterised by significant variations in the chlorine content which appear on a centennial scale with cycles of around 400 years.

\section{Coastal terraces}

Altitudes of the terraces have been measured with differential GPS at the northern and 


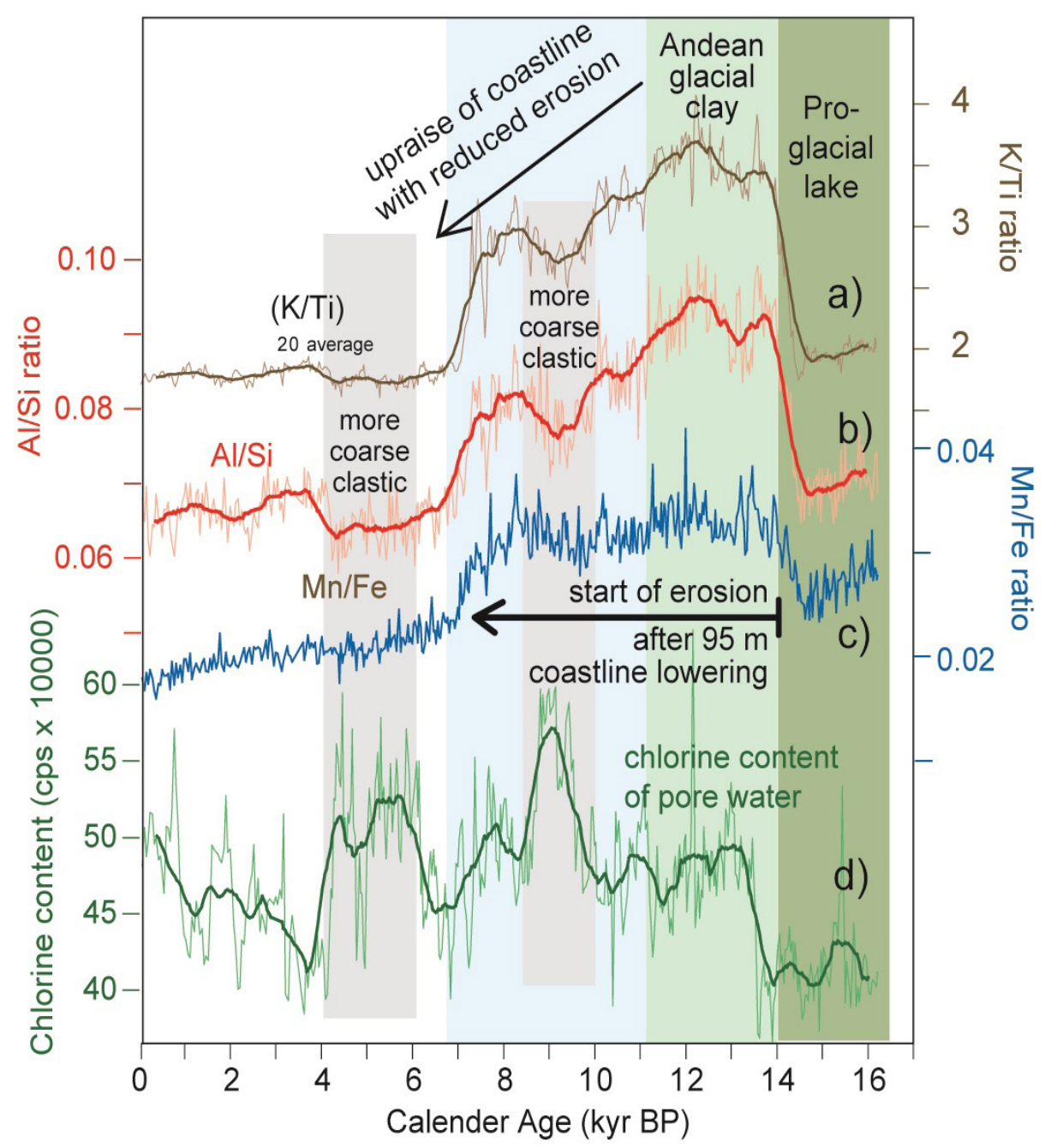

Fig. 5. OTW2 sediment core with a) $\mathrm{K} / \mathrm{Ti}$, b) $\mathrm{Al} / \mathrm{Si}$, c) $\mathrm{Mn} / \mathrm{Fe}$ ratios and d) chlorine content with 20 point running averages. Phases of more coarse clastic sedimentation are shown. The proglacial lake period and Andean clay signature are illustrated.

eastern Skyring shores along 20 profiles oriented perpendicular to the coast (lines in Figs. 2 and 8). The regional distribution of terraces $\mathrm{T} 1, \mathrm{~T} 2$ and T3 have been furthermore mapped by analysing SRTM data in the context of two diploma thesis (Michels, $2009^{4}$ and Wirtz, 20095).

\footnotetext{
${ }^{4}$ Michels, S. 2009. Rekonstruktion jungquartärer Hebungsraten anhand postglazialer Fjordterrassen in Südchile. Unpublished diploma thesis, Trier University.

5 Wirtz , J. 2009. Rekonstruktion spät- und postglazialer vertikaler Landbewegungen an Terrassen eines Fjordsystems in Südchile. Unpublished diploma thesis, Trier University.
}

Drainage, water pathways and paleo-terraces

Present day and possible past drainage and water path ways are shown in Fig. 3 together with their geomorphological characteristics which are summarized in the following.

The paleo spillway of the eastern Seno Otway flew eastward to the Cabeza de Mar inlet and to the Strait of Magellan as illustrated in Fig. 3a. The $8 \mathrm{~km}$ long channel is 100 to $170 \mathrm{~m}$ wide and its present-day elevation is 5 to $15 \mathrm{~m}$ a.s.l. It 
is incised about $10 \mathrm{~m}$ into an extended erosional terrace system (T2) with altitudes of 25 to $30 \mathrm{~m}$. T2 can be followed around the eastern shores of the Seno Otway, the Fitz Roy Channel and the whole eastern sector of Seno Skyring where it can be followed $60 \mathrm{~km}$ westward up to Escarpada Island (Fig. 7). The 14.8 kyr Reclus tephra layer (Stern et al. 2011) was found at two locations on this terrace system. Thus it indicates that T2 was formed at that time (white paleo shore line marked in Fig. 1).

The Jerónimo Channel forms a major pathway across the Andean mountain range of the southern Península Brunswick and Isla Riesco (Fig. 3b). At present it connects the Seno Otway with the Central part of the Strait of Magellan near to Isla Carlos III. The $40 \mathrm{~km}$ long channel is 0.85 to $3.1 \mathrm{~km}$ wide and has water depths of 70 to $100 \mathrm{~m}$. It is characterised by strong tide currents $(>4 \mathrm{~m} / \mathrm{s})$ and represents the major outflow path for precipitations in the Seno Otway and Seno Skyring area. With respect to the elevation of the surrounding mountains (up to $1200 \mathrm{~m}$ ) and analogue to the reconstructed glacier extensions around the GCN area and Cordillera Darwin (Kilian et al. 2007a; Boyd et al. 2008) it is most likely that the Jerónimo Channel was covered by glaciers during the Late Glacial until at least 15 to $14 \mathrm{kyr}$ BP (Fig. 3b). A second outflow pathway could have been established to the east of the channel through the Río Bachelor valley which has present-day altitudes up to $26 \mathrm{~m}$ a.s.l.

The Fitz Roy Channel is $18 \mathrm{~km}$ long (north-south-trending) and 0.4 to $1.2 \mathrm{~km}$ wide (Fig. 3a). This channel has present-day water depths of 10 to $20 \mathrm{~m}$ and is connecting the eastern sector of the Seno Skyring with that of Seno Otway. It is characterised by strong tide currents of up to 5 $\mathrm{m} / \mathrm{s}$. However, significantly longer periods of tide currents from Skyring towards the Otway indicate a significant outflow of the Skyring towards the Otway. An average outflow rate of $\sim 400 \mathrm{~m}^{3} / \mathrm{s}$ has been calculated for the year 1992 (Marangunic et al. 1992). The outflow rates can be partly enhanced due to wind-induced eastward transport of water masses in the Skyring which can produced $>1 \mathrm{~m}$ higher water levels at its eastern shores (Kilian et al. 2007b).

The Gajardo Channel with Angostura
Témpanos connects the western Seno Skyring with the Xaltegua Channel and the Strait of Magellan (51 km length). Near to the Gran Campo Nevado there is a $500 \mathrm{~m}$ long and $<100 \mathrm{~m}$ wide channel with a ridge with a water depth of $2.5 \mathrm{~m}$ and strong tide currents up to $8 \mathrm{~m} / \mathrm{s}$ (Fig. 3c; Kilian et al. 2007a). The W-E thermohaline profile along the Gajardo Channel and Seno Skyring (Fig. 8) shows inflow of marine water across this shallow passage which was very sensitive for Holocene isostatic changes in the range of few meters and associated water exchange rates. At around $15 \mathrm{cal}$ kyr BP the Gajardo Channel was covered by glaciers which reached until its north-northeastern entrance (Fig. 1; Stage D after Kilian et al. 2007a; McCulloch et al. 2005). Chandler Island is located within the Gajardo Channel (Fig. 3c), $10 \mathrm{~km}$ northeast of the Angostura Témpanos. A $6.5 \mathrm{~m}$ long sediment core $\mathrm{CH} 1$ has been drilled in the Chandler Lake on this island. Near the basis of the core a sharp transition from glacial clay to organic-bearing sediment gives an age of $12.3 \mathrm{cal} \mathrm{kyr} \mathrm{BP} \mathrm{(Kilian} \mathrm{et} \mathrm{al.} \mathrm{2007a).} \mathrm{This}$ indicates the retreat of the glaciers from Gajardo Channel towards the Gran Campo as indicated in Fig. 3c. The Early Holocene coastline evolution of this area remains unexplored, since no erosional terraces have been incised in the fjord slopes. However, the $\mathrm{CH} 1$ core of Chandler Lake which is situated at an elevation of $35 \mathrm{~m}$ a.s.l. did not indicate a marine transgression after the deposition of glacial clay at the core basis at $12.3 \mathrm{kyr} \mathrm{BP}$, when the global sea level was $60 \mathrm{~m}$ lower than today (Siddall et al. 2003). This limits the amount of isostasy since $12 \mathrm{kyr}$ BP to less than $95 \mathrm{~m}$. However, it is likely that the Angostura Témpanos fall dry during the early to mid-Holocene when the isostatic uplift was nearly finalized and the sea level reached nearly present day elevations (until 6 to 5.5 kyr BP). Afterwards the additional Neoglacial glacier upload (+>100 $\mathrm{m}$ ice) at the GCN could have lowered the coastline by 10 to $20 \mathrm{~m}$. It is also likely that Neoglacial glacier advances (5.4 to $5.1,4.4$ to $4.1,2.7$ to 2.2 ; 0.6 to 0.1 kyr. BP; e.g. Kilian et al. 2011; Mercer 1982) closed this passage sporadically as moraines from the Little Ice Age indicate (Fig. 3c; Kilian et al. 2007a; Koch \& Kilian, 2005). The Neoglacial glacier advance would have also limited the possible southward migration of canoeing Indians through the Gajardo 
Channel (Legoupil, 2000).

The paleo-connection between western Seno Skyring, Lago Muñoz Gamero and Seno Obstrucción (Paso de Indios)

Between a westernmost unnamed bay of Seno Skyring (to the South of Ensenada Rodriguez) and the Lago Muñoz Gamero there is a $500 \mathrm{~m}$ long and 30 to $50 \mathrm{~m}$ wide channel which was eroded by water flows in-between both hydrological systems (Fig. 3d). At present the ground of this channel reaches an elevation of up to $25 \mathrm{~m}$ a.s.l.. It has been suggested that this passage was used by Indians (Legoupil, 2000). In the bay which leads from the Seno Skyring to this passage two moraines are partly preserved, possibly reflecting also retreat stage D (Kilian et al. 2007a). Thus glaciers could have closed this passage during the early Deglacial. However, the mountains of this area have relatively low elevations (300 to $750 \mathrm{~m}$ a.s.l.) and thus the extent of these glaciers and the isostasy was probably more restricted compared to that of the GCN area. Similar paleo water pathways with present-day elevations of up to 30 $\mathrm{m}$ a.s.l. connected the eastern sector of the Lago Muñoz Gamero with the Seno Obstrucción at some time ago as the erosional channels indicate (Fig. 3d). They have been also used by as portages from canoeing Indians. To the west of Cordillera Pinto a flat valley represents a further possible past water pathway between Seno Skyring and Seno Obstrucción (Figs. 1, 2).

Western Gran Campo sector: Connection of Swett Channel to the Lago Muñoz Gamero

The drainage outflow region of Lago Muñoz Gamero to the west of the GCN represents another key area with respect to possible marine transgression to the Skyring area across the Lago Muñoz Gamero (Fig. 3e). During the Deglacial this area and the Swett Channel were covered by extended glaciers from the GCN. Sediment cores from the Isla Parlamento and Cabo Tamar, both located 35 to $40 \mathrm{~km}$ westward document, that the region became ice-free after 16 kyr BP (Kilian et al. 2007b; Figs. 1; PALM1 and TML in Fig. 2). However, it remains unclear when the
Swett Channel and outflow region of Lago Muñoz Gamero became ice-free.

A $9.8 \mathrm{~m}$ long sediment core BA1 from the shallow Arevalo Bay, $2 \mathrm{~km}$ westward of the Lago Muñoz Gamero outflow (Figs. 2 and 3e), shows coarse-clastic lacustrine sediments below the 4.2 kyr BP Mt. Burney tephra layer. This suggest that the coastline was around $>5 \mathrm{~m}$ lower previous to 4.5 kyr BP indicating that the coastline and riverinflow to these bay very nearest to the core site. Such a lower paleocoastline indicates that there was no marine transgression through the nearby outflow region of the Lago Munoz Gamero (LMG), at least during the middle Holocene. At present the LMG has a level of around $3.5 \mathrm{~m}$ a.s.l.

The present day proglacial lake of the 20 $\mathrm{km}$ long Glaciar Noreoeste of the GCN, located to the east of the outflow area of the LMG, experiences occasionally a marine transgression during extraordinary high tides (field observation of the authors; Fig. 3e). Moraine remnants indicate that this glacier probably closed the LGM outflow region during the most extended LIA advance 0.55 to 0.30 kyr BP and during the Neoglacial advance at 2.5-2.2 kyr BP. During these periods the LMG was probably draining into the Seno Skyring through the above described Paso de Indios and/or into the Seno Obstrucción. This could have caused an additional freshening of the Seno Skyring. However, is not obvious regarding the Neoglacial chlorine content changes in the BW2 sediment core of Bahía Williams (Fig. 6)

Hydrological, thermohaline and weather data

In the higher elevated mountains the annual precipitation ranges from 4000 to $>9500 \mathrm{~mm}$ in the time span of 1999 to 2012 (Schneider et al. 2003 and unpublished weather data of the authors). The precipitation correlates with increasing altitude. We estimate that at westerly exposed hill sites of $>500$ $\mathrm{m}$ a.s.l. the precipitations are nearly twice as high as at sea level. The average annual outflow rate of the LMG is calculated to $185 \mathrm{~m}^{3} / \mathrm{s}$ (Marangunic et al. 1992). This suggests a water supply of 7600 $\mathrm{mm}$ within the LMG catchment and an annual addition of $52400 \mathrm{~mm}$ water column in the lake area. This hydrological data are well corresponding with our precipitation data from the AWS around 


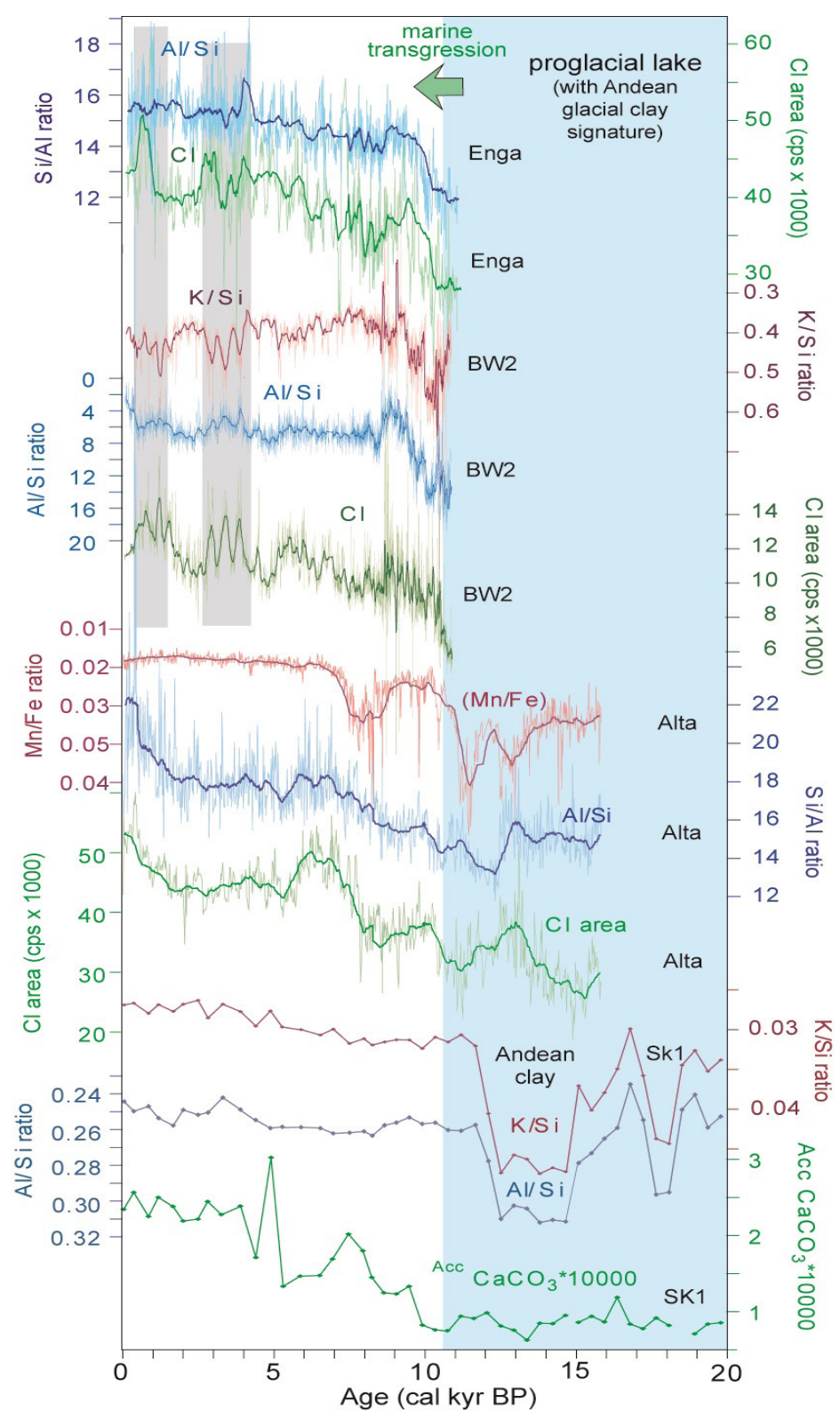

Fig. 6. Salinity-sensity proxies (accumulation rates of biogenic carbonate in Sk1 core and chlorine content in the cores ENGA, ALTA and BW2) are shown and indicate a proglacial lake stage. $\mathrm{Al} / \mathrm{Si}, \mathrm{K} / \mathrm{Si}$ and $\mathrm{Mn} / \mathrm{Fe}$ ratios are shown as indicators for siliciclastic sediment components. High $\mathrm{K} / \mathrm{Si}$ and $\mathrm{Al} / \mathrm{Si}$ ratios indicate the Andean clay signature core from the Seno Skyring with implications for marine transgression.

the Gran Campo (<4500 to $9800 \mathrm{~mm} /$ year).

The Skyring basin covers a large gradient in precipitation with more than $7000 \mathrm{~mm}$ in the Gran Campo area, around $1000 \mathrm{~mm}$ at the AWS Estancia Skyring and around $500 \mathrm{~mm}$ at Punta Arenas and probably at Río Verde (Schneider et al. 2003 and unpublished weather data of the authors). Marangunic et al. (1992) calculated an average outflow rate of the Skyring fjord system of $445 \mathrm{~m}^{3} / \mathrm{s}$. This corresponds to an average annual precipitation of $3600 \mathrm{~mm}$ within the Skyring basin and an annual water addition of $9200 \mathrm{~mm}$ within 

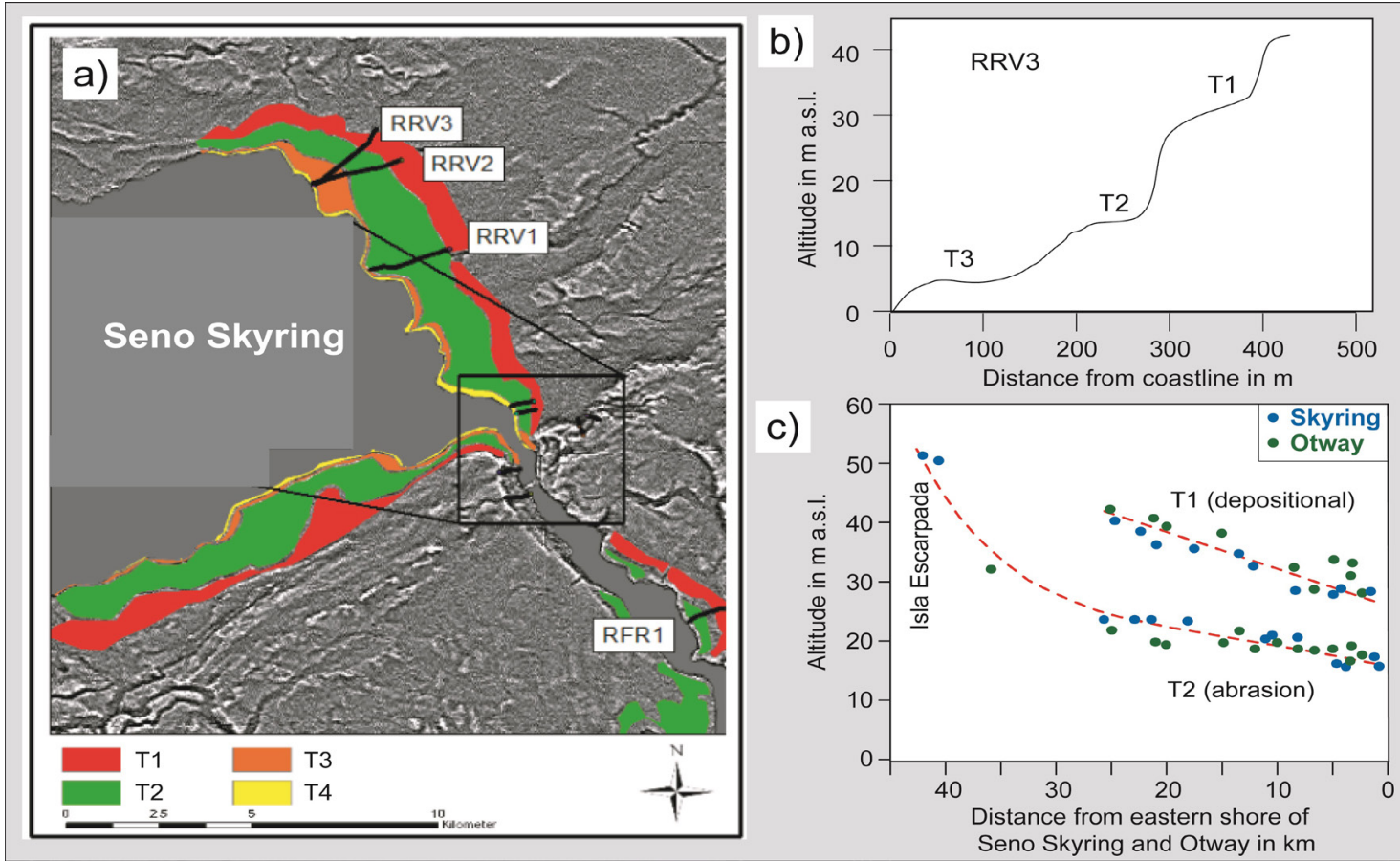

Fig. 7. Terraces mapped around the northern and eastern shores of the Seno Skyring and Seno Otway. a) The eastern sector of Seno Skyring with locations of profiles RRV1 to 3; b) Elevation of profile RRV3 with terraces T1 to T3 and c) Compilation of altitudes of determined from the Northern and Eastern shores of Seno Skyring and Seno Otway for the terraces T1 and T2.

the water area of the Skyring fjord system while the annual evaporation amounts to less than 500 $\mathrm{mm}$. The high freshwater supply explains the existence of a stable low salinity surface layer in the uppermost $80 \mathrm{~m}$ of the water column of the Skyring despite the strong average annual wind velocities. It seems to that the strong wind-induced currents do not affect the thermohaline layering. However, the $115 \mathrm{~km}$ long salinity profile from the Angostura Témpanos across Gajardo and Euston Channel until the eastern Skyring and Fitz Roy Channel (Fig. 9a) shows that the superficial fresh water layer is displaced eastward by the strong westerly winds (Kilian et al. 2007b) and that there is only a restricted bottom current with slightly higher salinities staring from Angostura Témpanos towards the Euston Channel (arrow in Fig. 9a). Water levels fluctuations in the Skyring area are strongly controlled by precipitation $( \pm 1 \mathrm{~m})$ and by wind action $( \pm 1 \mathrm{~m})$ while tides have only minor influences and can be only detected near to Angostura Témpanos and Fitz Roy Channel in the range of $10-20 \mathrm{~cm}$.

The western sector of Seno Otway also receives high annual precipitation. However, a large water masses exchange between Otway and the Strait of Magellan takes place through Jerónimo Channel. Thus the Otway has overall higher salinities than the Skyring. The CTD profile of Fig. 9b shows the lowest salinities of $<24$ psu near to the Fitz Roy Channel due to outflow of low salinity water from the Skyring. The salinity of the surface water layer increases westward up to $28 \mathrm{psu}$. Like in the Skyring area, the surface water salinities depend on precipitation and wind action, while relatively homogenous bottom water with salinities of 30 psu were measured below 80 $\mathrm{m}$ water depth during different annual seasons.

Sediment echo sounder data

Echo sounder sediment profiles of the Seno Otway show a continuous uppermost layer of less than $4.5 \mathrm{~m}$ thickness which is underlain by 
a strong reflector and a further sequence of clayey sediments of the early Late Glacial (Fig. 8; Breuer et al. 2013). The OTW2 core drilled at $74 \mathrm{~m}$ water depth shows this $4.5 \mathrm{~m}$ thick uppermost sediment sequence of Late Glacial and Holocene age. The above described transition (Chapter 2.1) from low chlorine content and organic-bearing sediment (Fig. $5 \mathrm{~d}$; Proglacial lake stage) to the glacial clay-bearing section at around $14 \mathrm{kyr} \mathrm{BP}$, can be seen as a pronounced reflector which occur as well in all echo sounder profiles across the Seno Otway. Along profiles taken at more than $70 \mathrm{~m}$ water depth (Fig. 8c) this reflector is underlain by concordant glacial sediment layers, while in the shallower profiles of less than $70 \mathrm{~m}$ there is a pronounced unconformity towards underlying sediment layers (Figs. 8a, b). This suggests that the Late Glacial sediment sequence has been strongly eroded, probably when paleo lake/fjord shores of less than $70 \mathrm{~m}$ presentday water depths became exposed after 14 Kyr BP (Fig. 8; Breuer et al. 2013).
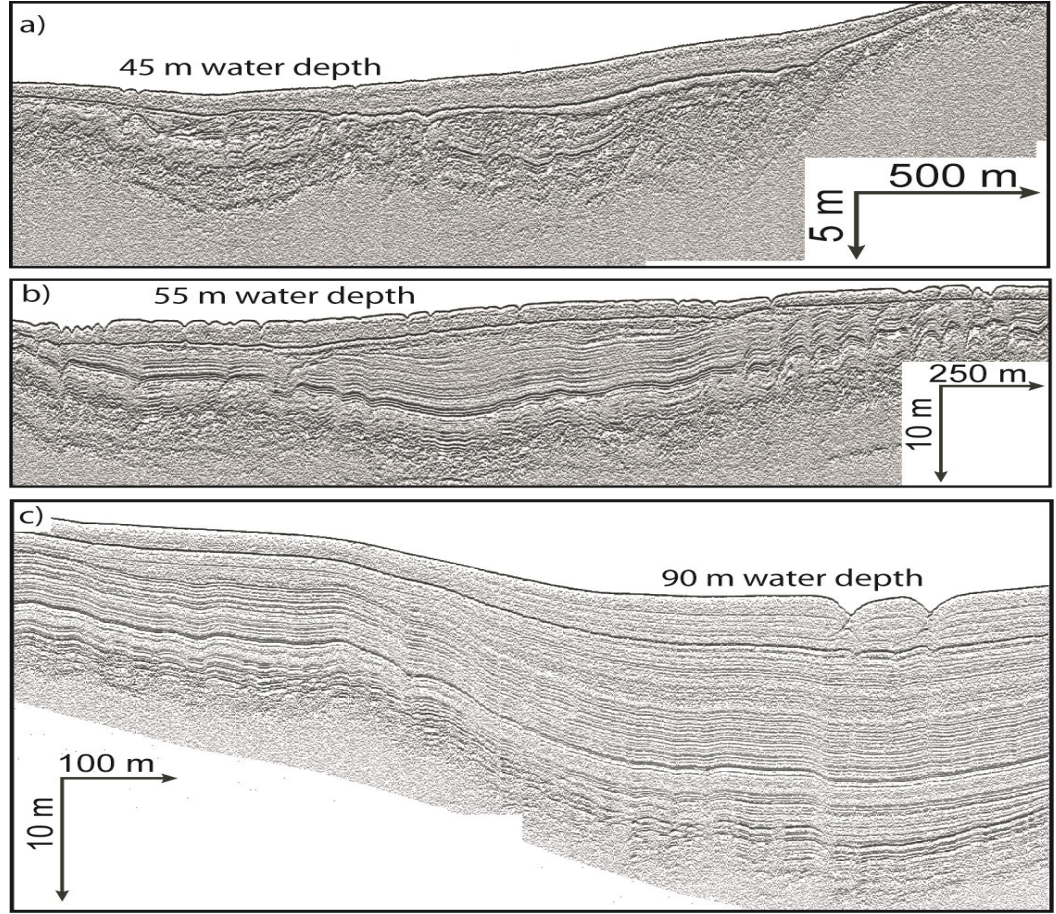

Fig. 8. Sediment echosounder profiles from Seno Otway (profiles a, b, c, are marked in Fig. 2). The two sections from shallower water depth show a distinct unconformity between the uppermost Late Glacial and Holocene layer, while in the deeper sector the transition is conformal.

\section{DISCUSSION}

\section{Marine transgression}

Depositional terraces (T1) of glacial detritus (gravel) were formed by melt water streams around the glacial lobes of Seno Skyring and Otway during the Late Glacial ( $>18$ kyr BP) in altitudes of 40 to $60 \mathrm{~m}$ a.s.l. (Figs. 1, 3, 8). After an early glacier retreat during the Late Glacial (Fig. 10a; <19-
15 kyr BP; retreat stages D to E; Baeza, 20056; Kilian et al. 2007a; Kilian \& Lamy, 2013; McCulloch et al. 2005; Stern et al. 2011) an interconnected abrasional terrace system (T2) was formed. This indicates the shores of an extended proglacial lake system which included the present day Lago Muñoz Gamero and Última Esperanza

6 Baeza, O. 2005. Lake and fjord sediments as Late Glacial to Holocene environmental and climate archives of the southernmost Andes at $53^{\circ} \mathrm{S}$, Chile. Ph.D. Thesis, Albert-Ludwigs-Universität Freiburg, Germany. 
fjord system (Fig. 10 b; Stern et al. 2011). With an area of $>5700 \mathrm{~km}^{2}$ this Magellan proglacial lake was the largest of the southernmost Andes. At two sites of the northern Skyring the 14.8 kyr BP Reclus tephra layer was identified within deposits of T2 indicating that it has been formed previously ${ }^{5}$. The altitudes of this terrace system increase continuously from around $\sim 25 \mathrm{~m}$ a.s.l. in the eastern Skyring to $>50 \mathrm{~m}$ a.s.l. at the Isla Escarpada located around $50 \mathrm{~km}$ further to the west (Fig. 7). This $25 \mathrm{~m}$ change in elevation of T2 indicates the minimum of isostatic rebound after 15 to $14 \mathrm{kyr} \mathrm{BP}$ in this sector which is still to the east of the higher elevated mountain belt where the glacier upload and isostasy was probably more extended. At that time the possible westward water pathways of this proglacial lake system (across the Jerónimo, Gajardo, Swett and Kirke Channels, and the Estero de las Montañas) were still occupied and dammed by glaciers (Figs. 1, 3, 10b). The higher paleocoastlines in the western lake sectors (due to higher previous glacier upload) indicate that there could have been established extended water pathways between the westernmost Skyring and the Lago Muñoz Gamero, and the Seno Obstrucción (part of the Última Esperanza fjord system) when the ice retreat was sufficiently advanced (Figs. 1, 2). The T2 distribution and altitudes also indicate that the Seno Skyring and Otway were connected by the Fitz Roy Channel which was much deeper $>25 \mathrm{~m}$ (compared to $10 \mathrm{~m}$ water depth at present) and broader (Fig. 7). Due to constrains by morphology and glacier flows the above described Magellan lake system was draining through the eastern shores of Seno Otway towards Cabeza del Mar and the Strait of Magellan (for details see Figs. 1, 2, 3a, 10 a,b). Mercer (1970) dated organic material from the floor of the ancient spillway which gave an age of 14.2 kyr BP (Fig. 3a). A change in the pollen assemblage at around 14 Kyr BP in a sediment record from a lake near Seno Ballena to the southwest of Isla Carlos III may indicate some glacier retreat (Fontana \& Bennett, 2012). Nearly coeval, at around 14 kyr BP, the OTW2 sediment core shows a significant increase in chlorine content and change in siliciclastic sediment composition (e.g. increase in $\mathrm{K} / \mathrm{Si}, \mathrm{Al} / \mathrm{Si}$; Fig. 5) which indicate a significant higher contribution of Andean glacial clay. On the one hand, this increase in glacial clay deposition can be explained by higher mobilization of clay in the Andes. However, this is unlikely since glaciers have been retreating at that time (Kilian \& Lamy, 2012). Furthermore, long distance transport of Andean glacial clay may have been hampered by increasing salinity and related flocculation (McCool \& Parson, 2004; Petrola et al. 2013). On the other hand the glacial clay was eroded from the lake shores which have been covered by thick glacial sediment deposits before they became suddenly exposed when the Jerónimo Channel was opened. Echo sounder profiles of the Otway (Fig. 8) indicate a significant erosion of Glacial and Late Glacial sediment layers at water depths less than $70 \mathrm{~m}$, while deeper sediment layers show a conformal layering of Glacial and Holocene sediment sequences. Considering the altitude of the T2 terraces (20-25 $\mathrm{m}$ a.s.l.) and the global sea level at 14 kyr BP (-70 m compared to present day sea level) a total lowering of the water level by $95 \mathrm{~m}$ is suggested. In the context of this scenario it is suggested that glacial clay has been strongly eroded from the abruptly exposed and vegetationfree shores for several millennia. After $10 \mathrm{kyr}$ BP the erosion was reduced due to further increase in the water level of the Seno Otway related to the global sea level rise (proceeding until 6 kyr BP) and by an increased expansion of the vegetation.

The outflowing water may have soon eroded the remaining glaciers in the Jerónimo Channel, like outflow events of the last century across Perito Moreno Glacier in the Lago Argentino document. It is most likely that the outburst produced a catastrophic flood event towards Isla Carlos III. This outflow from the Otway had an estimated volume of around $260 \mathrm{~km}^{3}$. Due to the shallow Fitz Roy Channel the Seno Skyring and possibly Seno Última Esperanza were only lowered by around 20 $\mathrm{m}$ and remained a proglacial lake from which a further outflow of $60 \mathrm{~km}^{3}$ may have been occurred through the Seno Otway and Jerónimo Channel. Further north a catastrophic outburst $\left(2000 \mathrm{~km}^{3}\right)$ of the Lago General Carrera is documented after the glacier retreat at 12.8 kyr BP (Turner et al. 2005).

The sediment cores from the Skyring area (SK1, ALTA1, BW2 and EN1; Fig. 6) indicate a significant increase of pore water chlorine content, accumulation rates of biogenic carbonate as well as 
a decrease in transport and accumulation rates of allochthonous Andean glacial clay (decease in $\mathrm{Al} /$ $\mathrm{Si}$ and $\mathrm{Ki} / \mathrm{Si}$ ratios, Fig. 6) between 11 and $10 \mathrm{kyr}$ $\mathrm{BP}$. These changes suggest at least a limited marine transgression. Since the easternmost T2 terrace system is at lower elevation and thus indicates a reduced isostatic rebound, it is unlikely that the globally upraising sea and coastline levels provoked first a marine transgression across the Fitz Roy Channel. This water pathway may have been established first after 6 kyr BP when the global sea level rise reached its maximum (Siddall et al. 2003; Fig $10 \mathrm{~d}, e)$.

The well-dated transition between glacial clay and organic-bearing sediments in the $\mathrm{CH} 1$ lake core from Chandler Island in the middle sector of the Gajardo Channel indicates a glacier retreat at around $12.3 \mathrm{cal} \mathrm{kyr} \mathrm{BP} \mathrm{(Fig.} \mathrm{4;} \mathrm{Kilian} \mathrm{et} \mathrm{al.}$ 2007a). Furthermore a pollen record from a nearby fjord shore (GC2, Fig. 3c Fesq-Martin et al. 2005) indicates moraine-typical plant communities at that time and until 11 kyr BP before the Magellan rain

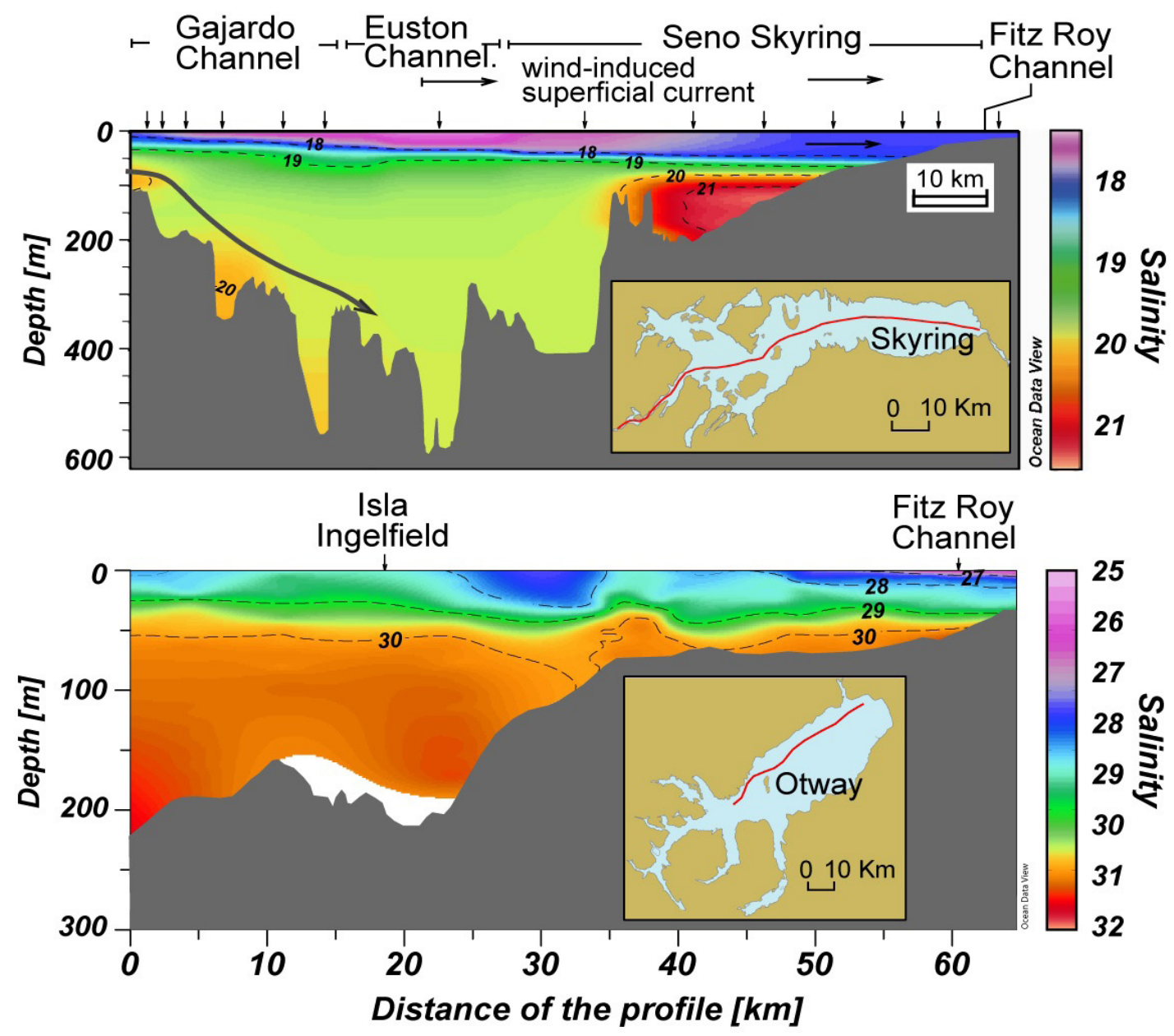

Fig. 9. Thermohaline conditions along a $115 \mathrm{~km} \mathrm{E-W}$ transect from Angostura Tempanos within the Gajardo Channel until the Eastern Seno Skyring near to the Fitz Roy Channel (upper profile; Kilian et al. 2007b); B (lower profile) and along a $80 \mathrm{~km}$ long E-W transect from the Northern End of Jeronimo Channel until the eastern Seno Otway near to the the Southern mouth of Fitz Roy Channel (lower profile). The geographical distributions of profiles are marked in inset maps. 
forest expanded. Therefore it is most likely that the marine transgression to the Seno Skyring occurred at first thru the Angostura Témpanos at around 11 kyr BP. Alternatively or in addition a marine transgression could have been appeared thru the Swett Channel into the area of the present day Lago Muñoz Gamero (Fig. 3e; 10 d) which was assumed to be still connected with Seno Skyring at that time.

Between 11 to 9 kyr BP the sediment cores from the northern Skyring coast (BW2 and ALTA1; Fig. 2) show a systematic transition from coarse to more fine-clastic sediments. This was interpreted as an increase in coast-line elevation which resulted in a reduced input of coarse clastic sediments by the coastal tributaries. Besides a possible restricted change of the coast line elevation by the regional tectonic movements, the ongoing global sea level rise could have been provoked an increase of coastline elevation after the marine transgression at around 10.5 kyr BP along the Seno Skyring. Between 11 and 9 kyr BP the sea level rose $40 \mathrm{~m}$ (20 mm/yr). This is more than T2 terrace systems indicate for this Skyring sector where the isostatic uplift after 14 kyr BP has been estimated to around $+25 \mathrm{~m}$.

\section{Tephra depositions}

In the Seno Skyring area several tephra layers were deposited during the Late Glacial (Kilian et al. 2003; Stern, 2008) and each of them may have been accompanied by more and less extended rework phases. This rework and erosion of the tephra has affected terrestrial plant communities and the aquatic bioproductivity, in particular after the 4.15 kyr eruption of Mt. Burney (Kilian et al.
18 kyr BP

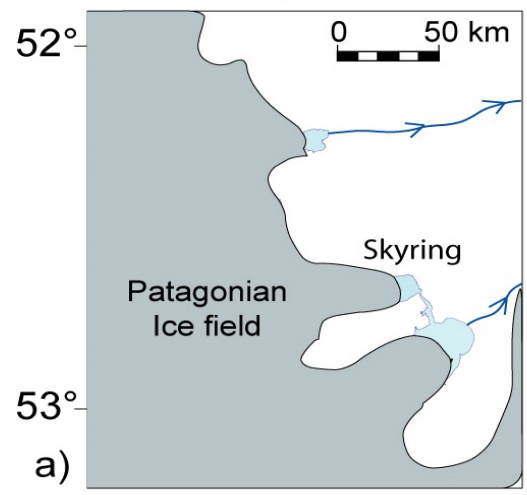

11 kyr BP

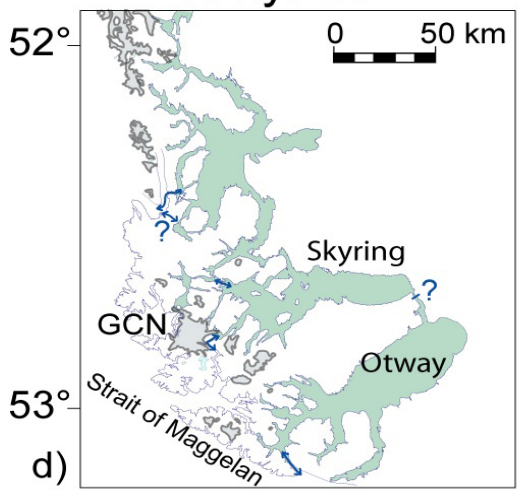

15 kyr BP

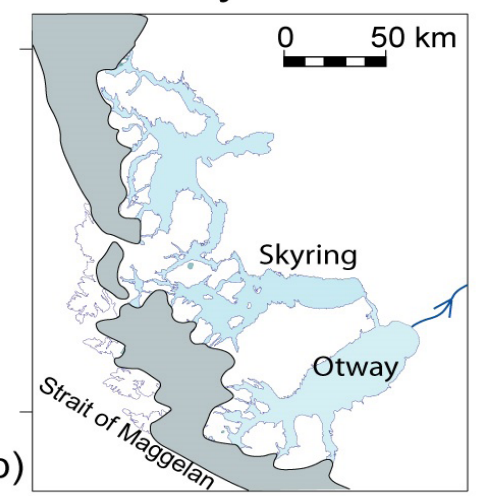

6 kyr BP

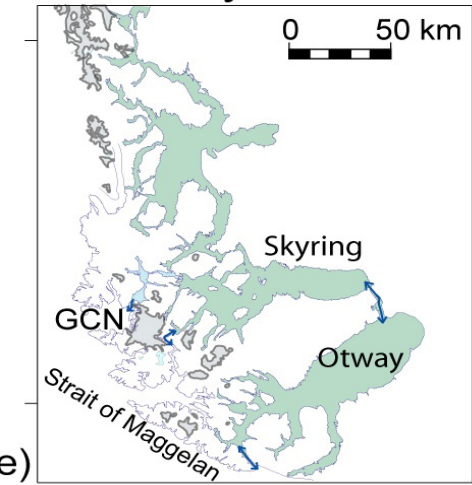

14 kyr BP

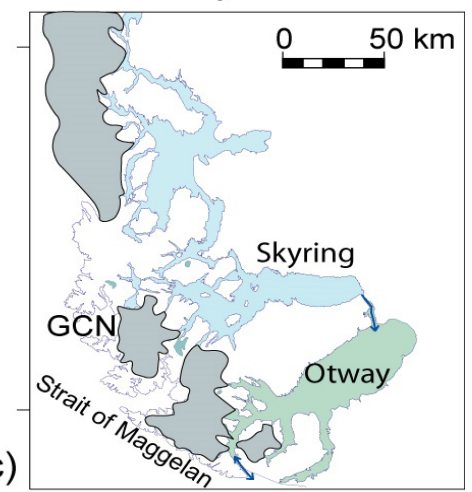

0.5 kyr BP

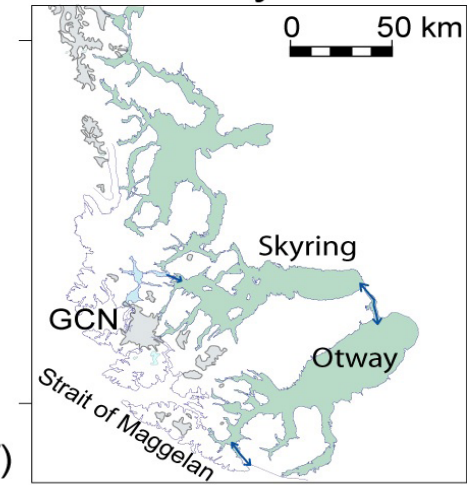

Fig. 10. Stages of glacier retreat and marine transgression towards the Seno Skyring and Otway proglacial lake system at (a) 18 kyr BP, (b)15 kyr (Proglacial lake stage), (c)14 kyr BP (opening of Jerónimo), (d) 10 kyr BP (opening of Gajardo Channel), (e) 6 kyr BP (end of global sea level rise) and, (f) $0.5 \mathrm{BP}$ (Neoglacial glacier advances). 
2006). However, the thickness of tephra layers found in open fjord sites (SK1, ME1 and OTW2) in water depths of more than $70 \mathrm{~m}$ does often not reflect the original tephra fall on the water surface, since light pumices have been redistributes by wind and water currents. Records from shallower fjord bays (Fig. 4; e.g. ALTA1, BW2, ME1, ES1), lakes $(\mathrm{CH} 1)$ and peat (GC2) could provide more reliable data.

Late glacial and Holocene tephra layers in the Seno Skyring area have been previously investigated by Kilian et al. (2003, 2006) at 22 sites and by Stern (2008; Laguna Escondida: ES1 in Fig. 2). Here we consider further 7 sediment records including the Seno Otway. Previously determined tephra depositions in this area are from the Mt. Burney (2.0, 4.15 and 9.05 kyr BP), from Aguilera (3.1 kyr BP), Hudson (8.1 kyr BP) and Reclus $(\sim 15.0$ kyr BP). The new sediment cores have been investigated with respect to these known or other still unknown tephra layers based on microscopy and magnetic susceptibilities. Furthermore, samples containing tephra have been investigated for grain size, texture and mineralogy by scatter electron microscope and by chemical analyses of the volcanic glass and whole composition (Kilian et al. 2003; Stern \& Kilian, 1996).

Fig. 4 summarizes tephra records from marine and lacustrine sediment cores from the Otway and Skyring area. The thickness of tephra layer is less in the deep fjord sediment cores (e.g. OTW2 and SK1) than in associated coastal or on-land sites. This can be related to floating and wind-induced surface water transport of the tephra. The tephra of the 15 kyr BP Reclus eruption was found only in the SK1 core as $2 \mathrm{~mm}$ thick layer ${ }^{6}$. For this eruption the isopachs of tephra thickness are not clearly constrained (Stern, 2008). The tephra layer of the 9.05 kyr BP of the Mt. Burney appears relatively thin $(<2 \mathrm{~mm})$ in the $\mathrm{GCN}$ area and western Isla Riesco, but it becomes relatively thick $(5->10 \mathrm{~cm})$ at the northern shores of the Seno Skyring (OTW2, ALTA1; BW2) documenting their predominant eastward distribution (Stern, 2008). The 8.1 kyr BP Hudson layer was observed as $1-3 \mathrm{~mm}$ thick layer in several records (Fig. 4). However, changes in the isopachs are not clear for the investigated area.
The predominant south-eastern distribution of the tephra plume of the $4.15 \mathrm{kyr} \mathrm{BP}$ eruption of the Mt. Burney can be seen in all records with maximum thicknesses in the sector of the Gran Campo Nevado (up to $15 \mathrm{~cm}$ ) and western Isla Riesco (Kilian et al. 2006; Fig. 4). The 3.3 kyr BP Aguilera tephra was detected in several records as $1-2 \mathrm{~mm}$ thin layer. The distribution of the 2 kyr Mt. Burney eruption was more restricted. It appears as a 1-2 $\mathrm{mm}$ thick layer at some sites near the GCN (CH2, LM1, MA1 stalagmite; Figs 2 and 3) suggesting a smaller eruption column which was distributed mainly towards the SSE of the volcano.

Holocene fluctuations in sediment transport and event depositions

The OTW2 core shows significant variations of the porewater chlorine content during the last 13 kyr BP (Fig. 5). Millennium scale phases with higher chlorine content are documented from 10 to $8 \mathrm{kyr} \mathrm{BP}$ and 6 to $4 \mathrm{kyr}$ BP. They cannot be clearly associated to known regional climate perturbations (Kilian \& Lamy, 2012). However, the phases of higher chlorine content are correlated with a reduced accumulation of glacial clay components (lower $\mathrm{K} / \mathrm{Si}$ and $\mathrm{Al} / \mathrm{Si}$ ratios; probably eroded from the shores around the Seno Otway). A possible explanation can be that a lower precipitation caused less intense glacial clay transport from still glaciate areas around the Northern GCN and/or that higher salinities in the Otway surface water caused a faster flocculation of clay and therefore accelerated aspatially different clay sedimentation. The faster flocculation process of clay minerals hampers the transport of fine grained sediment components (e.g. McCool \& Parson, 2004; Portela et al. 2013).

The accumulation rates of biogenic carbonate in the SK1 core may reflect at least changes in the salinity (Fig. 5). At this site the allochthonous sediment transport (characterized by high $\mathrm{Al} / \mathrm{Si}$ and $\mathrm{K} / \mathrm{Si}$ ratios) was decreasing throughout the Holocene which can be related to slightly higher salinities and related flocculation of clay minerals (McCool \& Parson, 2004; Portela et al. 2013). The early Holocene increase of coastline elevations (around 10-15 m) at the BW2 
and ALTA1 sites at the northern coast of Seno Skyring could reflect an increase of the marine water transgression to Seno Skyring which would have hampered clay mineral transport by increased flocculation as discussed above. Alternatively a long-term decrease in glacial clay bearing sediment from the higher elevated mountains, located further to the west, can be also explained by reduced westerly intensities. This would have decreased the eastward sediment transport within the uppermost water layer consistent with other paleoclimate records from this Andean sector (Fig. 8; Lamy et al. 2010).

In the EN1 and BW2 core the chlorine content is slightly increasing throughout the Holocene, but this may be partly related to a general increase in pore water content from 40 to $55 \%$ (Fig. 6). Br content measured in separated aquatic carbon samples of BW2 does not suggest significant changes in the salinity throughout the Holocene (Kremer, 2009). However, both previously mentioned sediment cores show significantly higher chlorine contents during the period from 3.5 to $2.5 \mathrm{kyr} \mathrm{BP}$, and from 1.0 to 0.1 kyr BP associated with changes in mineralogical and chemical parameters. It is suggested that these changes in sediment composition reflect at least some salinity changes at that time. During this periods several records world-wide (Wanner et al. 2008, 2011) and from Patagonian (Chambers et al. 2007; Kilian \& Lamy, 2012; Schimpf et al. 2011; Van Geel et al. 2000) indicate significant climate perturbations. Higher salinities in the Seno Skyring can be interpreted by higher marine inflow rates at Angostura Témpanos, by reduced precipitation and/or increased evaporation. The MA1 stalagmite record from the Westside of the GCN indicates colder and dryer conditions for these periods (Schimpf et al. 2011) which could explain an increase in salinity. More advance glacier at that time (e.g. Glasser et al. 2004; Mercer, 1982) could have lowered the coastline by isostasy around the GCN area. This could have enabled also more inflow of marine water, but only if glaciers did not dammed the Gajardo Channel. Higher K/Si and $\mathrm{Al} / \mathrm{Si}$ ratios (Fig. 6) during these periods suggest higher mobilization rates of glacial clay from areas where the Patagonian Batholith is exposed, like at the GCN.
Present-day hydrogeographical and thermohaline conditions

The western sector of Seno Otway and Seno Skyring receive an annual precipitation in excess of $5000 \mathrm{~mm}$ (Schneider et al. 2003 and unpublished AWS data from 2003 to 2012). AWS stations around the GCN document a significant increase of precipitation with elevation, reaching up to $>10000 \mathrm{~mm} /$ year at elevations of $>500 \mathrm{~m}$ a.s.l. This causes an annual addition of 10000 to $20000 \mathrm{~mm}$ freshwater column in the fjords around the higher elevated mountains (e.g. GCN, Cerro Ladrillero) and up to $52000 \mathrm{~mm}$ onto the Lago Muñoz Gamero (Marangunic et al. 1992).

The freshening of the surface water is even more pronounced during storm periods which often last 2-3 weeks and led to an increase of $>1$ $m$ of the fjord water level (Kilian et al. 2013). It is most likely that a strong increase in surface water freshening during storm periods cause a significant stress to at least some of the aquatic species (e.g. Horton \& Murray, 2007).

At time scales of weeks to months orbital induced changes (sun and moon configuration) provokes changes in the intensity and direction of tidal currents at Angostura Témpanos and Jerónimo Channel. This causes variations in the amount of inflowing marine water to some regions of the fjord system with further implications concerning the bioproductivity in this area. Wind action has a strong influence on the water levels in both Seno Skyring and Seno Otway $( \pm 1 \mathrm{~m})$ and causes also surface water currents with velocities of $1-3 \mathrm{~km} /$ hour, mainly in the direction west to east.

Despite the strong influence of wind with respect to superficial currents, the water column of the Seno Skyring has a very stable density stratification throughout the seasonal course. This is also related to the whole year-round freshwater addition (Kilian et al. 2007b). Below $100 \mathrm{~m}$ water depth the water column does not show any seasonal variations and remains very stable throughout periods of various years or possible up to decades or even longer periods. An isolated bottom water body with higher salinities than in the bottom water column within the middle Skyring sector indicates this stable stratification (Fig. 9a; 
Kilian et al. 2007b).

Compared to the precipitation-related freshening the effect of evaporation on the thermohaline structure (less than $500 \mathrm{~mm}$ evaporation per year) seems to be of minor importance and mainly affecting the easternmost sectors of Seno Skyring and Seno Otway.

The thermohaline structure of the Seno Otway is characterised by a higher variability throughout the seasonal course. While low salinity waters enter the Seno Otway through the Fitz Roy Channel on one side and from the western most fjord appendices by precipitation on the other side (Fig. 9b). Relatively large amounts of water with higher salinity and more enriched with nutrients enters the Seno Otway through the Jerónimo Channel partly as bottom water current. However this fjord system requires further thermohaline profiles to improve understanding of possible fjord currents.

Future research perspectives

Among various open questions some key areas are suggested in the following where future sediment core drilling could significantly improve the knowledge of the marine transgression. Drilling around the Isla Carlos III would provide further constraints concerning the mega outflow event of the Seno Otway at around 14 kyr BP. It is also important to understand how far the associated erosion of glacial clay at the lake shores around the Seno Otway, exposed after lowering of the water surface by $-95 \mathrm{~m}$, and the enhanced sediment load would have been distributed into the Strait of Magellan throughout the Early Holocene and the associated implication for the regional aquatic ecosystems. Sediment drilling within the Muñoz Gamero lake may indicate how far and often there have been marine transgressions into this lake and the timing of the Late Glacial glacier retreat as well as Neoglacial glacier fluctuations (Glacier Noroeste from GCN). Age determination of subaquatic moraine ridges and the few remnants of terrestrial moraines (including cosmogenic exposure ages) as well as age determination of terrace systems would be very important for a better understanding of the paleogeographical and paleoecological evolution in this area.

\section{LITERATURE CITED}

Boyd, B., J. Anderson, J. Wellner \& R. Fernández (2008). The sedimentary record of glacial retreat, Marinelli Fjord, Patagonia: Regional correlations and climate ties. Marine Geology, 255(3-4):165-178.

Breuer, S., R. Kilian, W. Weinrebe, D. Schörner \& J. Behrmann (2013). Glacier and tectonic control on fjord morphology and sediment deposition in the Magellan region $\left(53^{\circ} \mathrm{S}\right)$. Marine Geology, 346:31-46.

Caniupán, M., F. Lamy, C.B. Lange, J. Kaiser, H.W. Arz, R. Kilian, O. Baeza-Urrea, C. Aracena, D. Hebbeln, C.Kissel, C. Laj, G. Mollenhauer, \& R. Tiedemann (2011). Millennial-scale sea surface temperature and Patagonian Ice Sheet changes off southernmost Chile $\left(53^{\circ} \mathrm{S}\right)$ over the past 60 kyr. Paleooceanography, 26(PA3221):110.

Chambers, F., D. Mauquoy, S. Brain, M. Blaauw \& J. Daniell (2007). Globally synchronous climate change 2800 years ago: proxy data from peat in South America. Earth and Planetary Science Letters, 253(34):439-444.

Clapperton, C.M., D.E. Sugden, D. Kauffman \& R.D. McCulloch (1995). The last glaciation in central Magellan Strait, southermost Chile. Quaternary Research, 44:133148.

Diraison, M., P.R. Cobbold, D. Gapais \& E.A. Rossello (1997). Magellan Strait: part of a Neogene rift system. Geology, 25:703706.

Fesq-Martin, M., A. Friedmann, M. Peters, J. Behrmann \& R. Kilian (2004). Late-glacial and Holocene vegetation history of the Magellanic rain forest in southwestern Patagonia, Chile. Vegetation History and Archaeobotany, 13(4):249-255.

Fontana, S.L. \& K.D. Bennett (2012). Postglacial vegetation dynamics of western Tierra del Fuego. The Holocene, 22(11):13371350.

Glasser, N.F., S. Harrison, V. Winchester \& M. Aniya (2004). Late Pleistocene and 
Holocene palaeoclimate and glacier fluctuations in Patagonia. Global and Planetary Change, 43(1-2):79-101.

Hogg, A., Q. Hua, P. Blackwell, M. Niu, C. Buck, T. Guilderson, T. Heaton, J. Palmer, P. Reimer, R. Reimer, C. Turney \& S. Zimmerman (2013). SHCal13 Southern Hemisphere Calibration, 0-50,000 years cal BP. Radiocarbon, 55(4):1889-1903.

Horton, B.P. \& J. W. Murray (2007). The roles of elevation and salinity as primary controls on living foraminiferal distributions: Cowpen Marsh, Tees Estuary, UK. Marine Micropaleontology, 63:169-186.

Kaplan, M.R., C.J. Fogwill, D.E. Sugden, N.R.J. Hulton, P.W. Kubik, \& S.P.H.T. Freeman (2008). Southern Patagonian glacial chronology for the Last Glacial period and implications for Southern Ocean climate. Quaternary Science Reviews, 27(34):284-294.

Kilian R. \& F. Lamy (2012). A review of Glacial and Holocene paleoclimate records from southernmost Patagonia $\left(49-55^{\circ} \mathrm{S}\right)$. Quaternary Science Reviews, 53:1-23.

Kilian, R., F. Lamy \& H. Arz (2013). Late Quaternary variations of the southern westerly wind belt and its influences on aquatic ecosystems and glacier extend within the southernmost Andes. German Journal Geoscience, 164 (2):279-294.

Kilian, R., M. Hohner, H. Biester, H. WallrabeAdams \& Ch. Stern (2003). Holocene peat and lake sediment tephra record from the southernmost Chilean Andes (53-55으. Revista Geológica de Chile, 30(1):47-64.

Kilian, R., H. Biester, J. Behrmann, O. Baeza, M. Fesq-Martin, M. Hohner, D. Schimpf, A. Friedmann \& A. Mangini (2006). Millennium-scale volcanic impact on a superhumid and pristine ecosystem. Geology, 34(8):609-612.

Kilian, R., C. Schneider, J. Koch, M. Fesq-Martin, H. Biester, G. Casassa, M. Arévalo, G. Wendt, O. Baeza \& J. Behrmann (2007a). Palaeoecological constraint on late Glacial and Holocene ice retreat in the Southern Andes $\left(53^{\circ}\right.$ S). Global and Planetary Change, 59(1-4):49-66.
Kilian, R., O. Baeza, T. Steinke, M. Arévalo, C. Ríos \& C. Schneider (2007b). Late Pleistocene to Holocene marine transgression and thermohaline control on sediment transport in the western Magellanes fjord system of Chile (53ㅇ). Quaternary International, 161(1):90-107.

Koch, J. \& R. Kilian (2005). Little Ice Age glacier fluctuations, Gran Campo Nevado, southernmost Chile. The Holocene, 15(1):20-28.

Lamy, F., R. Kilian, H. Arz, J. Francois, J. Kaiser, M. Prange \& T. Steinke (2010). Holocene changes in the position and intensity of the southern westerly wind belt. Nature Geoscience, 3(10):695-699.

Legoupil, D. (2000). El Sistema socioeconomico de los nomades del mar de Skyring (Archipiélago de Patagonia). Anales del Instituto Patagonia, Serie C.s., Hs., 28:81-119.

Lovell H., C.R. Stokes \& M.J. Bentley (2011). A glacial geomorphological map of the Seno Skyring Seno Otway-Strait of Magellan region, southernmost Patagonia. Journal of Maps, 7(1):318-339.

Marangunic, C., C. Parraguez, L. Stowhas, A. Lucchini \& L. Avila (1992). Estudio Hidrológico de los Proyectos Hidroeléctricos Skyring y Esperanza. Geoestudios, Proyecto ALCHI, Santiago, Chile.

McCool, W.W. \& J.D. Parsons (2004). Sedimentation from buoyant fine-grained suspensions. Continental Shelf Research, 24(10):1129-1142.

McCulloch, R., C. Fogwill, D. Sugden, M. Bentley \& P. Kubik (2005). Chronology of the last glaciation in central Strait of Magellan and Bahía Inútil, southernmost South America. Geografiska Annaler: Series A, Physical Geography, 87(2):289-312.

Mercer, J.H. (1970). Variations of some Patagonian glaciers since the Late Glacial. American Journal of Science, 269(6):1-25.

Mercer, J.H. (1982). Holocene glacial variations in southern South America. Striae, 18:3540.

Portela, I. L., S. Ramos \& A.T. Teixeira (2013). 
Effect of salinity on the settling velocity of fine sediments of harbour basin. Journal of Coastal Research, 65:1188-1193.

Sauter, T., C. Schneider, R. Kilian \& M. Moritz (2009). Simulation and Analysis of Runoff from a partly glaciated meso-scale Catchment area in Patagonia using an Artificial Neural Network. Hydrological Processes, 23:1019-1030.

Schimpf, D., R. Kilian, A. Kronz, K. Simon, C. Spötl, G. Wörner, M. Deininger \& A. Mangini (2011). The significance of chemical, isotopic, and detrital components in three coeval stalagmites from the superhumid southernmost Andes $\left(53^{\circ} \mathrm{S}\right)$ as high-resolution palaeo-climate proxies. Quaternary Science Reviews, 30(3-4):443-459.

Schneider, C., R. Kilian, A. Santana, N. Butorovic \& G. Casassa (2003). Weather observations across the southern Andes at $53^{\circ} \mathrm{S}$. Physical Geography, 24(2):97119.

Schneider, C., M. Schnirch, C. Acuña, G. Casassa \& R. Kilian (2007). Glacier inventory of the Gran Campo Nevado Ice Cap in the Southern Andes and glacier changes observed during the recent decades. Global and Planetary Change, 59(1-4):125.

Siddall, M., E.J. Rohling, A. Almogi-Labin, Ch. Hemleben, D. Meischner, D.A. Schmelzer \& D. Smeed (2003). Sea level fluctuations during the last glacial cycle. Nature, 423:853-858.

Stern, C.R. (2008). Holocene tephrochronology record of large explosive eruptions in the southernmost Patagonia Andes. Bulletin of Volcanology, 70(4):435-454.

Stern, C.R. \& R. Kilian (1996). Role of the subducted slab, mantle wedge and continental crust in the generation of adakites from the Andean Austral Volcanic Zone. Contributions to Mineralogy and Petrology, 123(3):263-281.

Stern, C.R., P.I. Moreno, R. Villa-Martínez, E.A.
Sagredo, A. Prieto \& R. Labarca (2011). Evolution of ice-dammed proglacial lakes in Última Esperanza, Chile: implications from the late-glacial R1 eruption of Reclús volcano, Andean Austral Volcanic Zone. Andean Geology, 38(1):82-97.

Sugden, D., M. Bentley, M. Fogwill, N. Hulton, R. McCulloch \& R. Purves (2005). Lateglacial glacier events in southernmost South America: a blend of 'northern' and 'southern' hemispheric climatic signals?. Geografiska Annaler: Series A, Physical Geography, 87(2):273-288.

Sugden, D.E., R.D. McCulloch, A.J.M. Boryd \& A.S. Hein (2009). Influence of Patagonian glaciers on Antarctic dust deposition during the last glacial period. Nature Geoscience, 2(4):281-285.

Turner, K.J., C.J. Fogwill, R.D. McCulloch \& D. E. Sugden (2005). Deglaciation of the eastern flank of the North Patagonian Icefield and associated continental-scale lake source. Geografiska Annaler. Series A, Physical Geography, 87(2):363-374.

Van Geel, B., C.J. Heusser, H. Renssen \& C.J.E. Schuurmans (2000). Climatic change in Chile at around $2700 \mathrm{BP}$ and global evidence for solar forcing: a hypothesis. The Holocene, 10:659-664.

Wanner, H., J. Beer, J. Bütikofer, T.J. Crowley, U. Cubasch, J. Flückiger, H. Goosse, M. Grosjean, F. Joos, J.O. Kaplan, M. Küttel, S. Müller, I.C. Prentice, O. Solomina, T.F. Stocker, P. Tarasov, M. Wagner \& M. Widmann (2008). Mid- to late Holocene climate change: an overview. Quaternary Science Reviews, 27:1791-1828.

Wanner, H., O. Solomina, M. Grosjean, S. Ritz $\&$ M. Jetel (2011). Structure and origin of Holocene cold events. Quaternary Science Reviews, 30(21-22):3109-3123.

Warren, C. \& D.E. Sugden (1993). The Patagonian Icefields: A Glaciological Review. Arctic and Alpine Research, 25(4):316-331. 